\title{
تأثير المنهج الاستراتيجي في فاعلية المشروعات الصغيرة والمتوسطة في العراق- بحث هيداني
}

الباحث/ ساره عبد القادر جبار

أ.د. سعد علي حمود العنزي

كلية الادارة والاقتصاد/ جامعة بغداد/ قسم ادارة الاعمال

: المستخاصى

الغرض من هذا البحث تسليط الضوء على تحقيق فاعلية المشروعات الصغيرة والمتوسطة بأبعاده وفقآ لتحليل

العلاقة بين استراتيجيات الاعمال واستراتيجيات ادارة الموارد البشرية ، وانطلق البحث من معضلة فئل فكرية باثارة تساولات

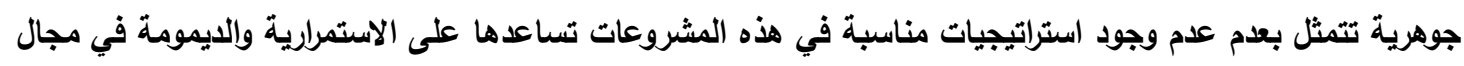

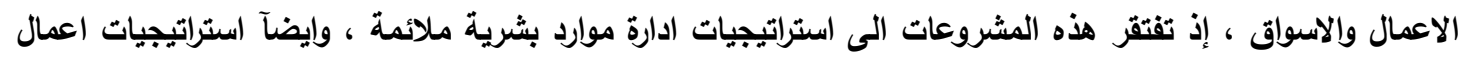

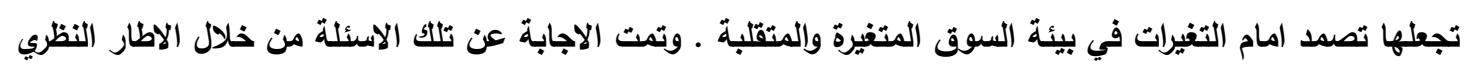

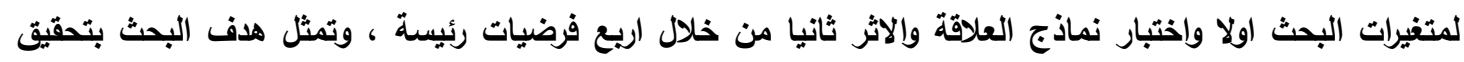

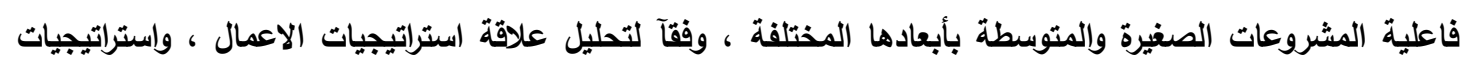

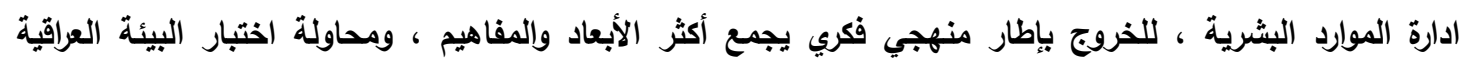

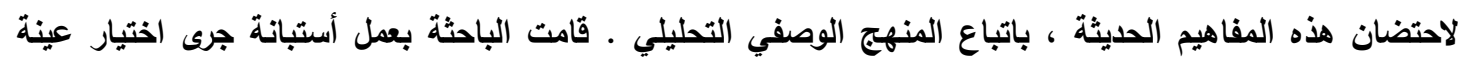

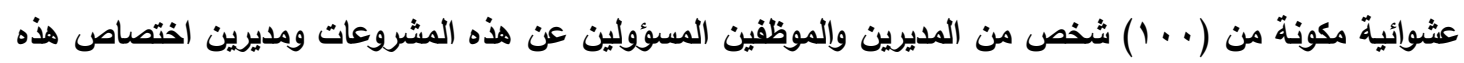

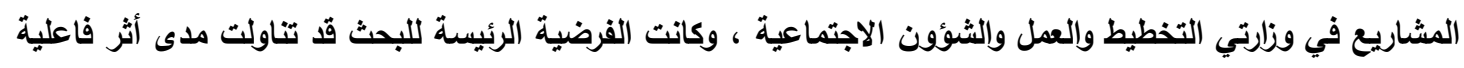

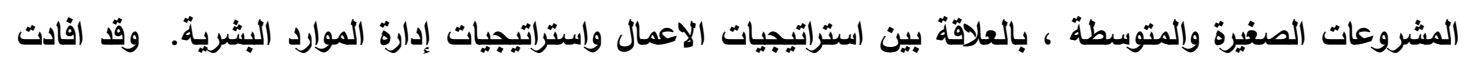

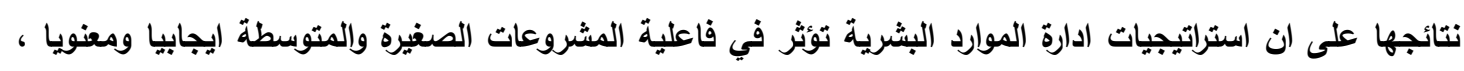

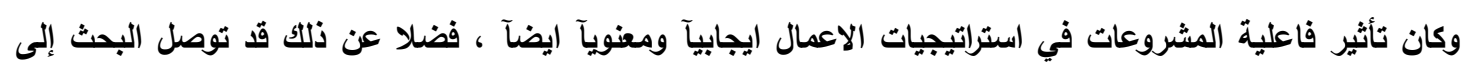

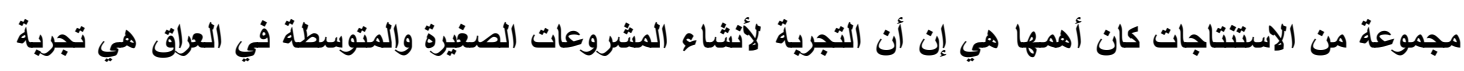

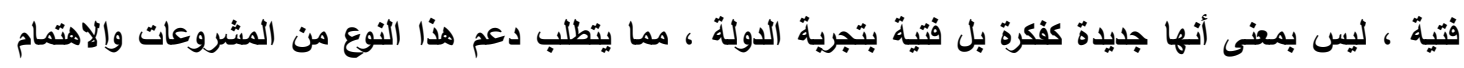

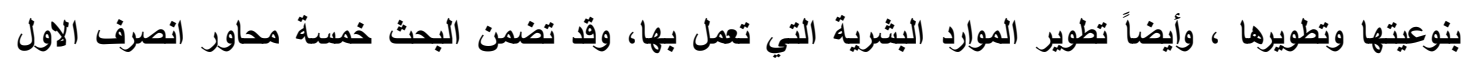

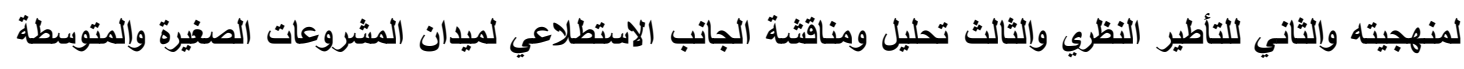

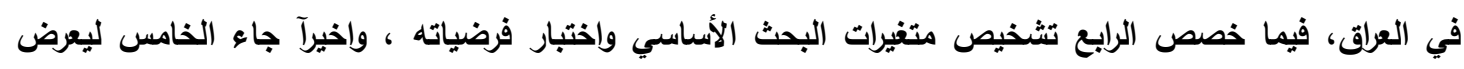

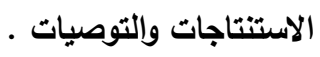

المسطحات الرئيسية لابحث/ المشروعات الصغيرة والمتوسطة- الفاعلية- استراتيجيات الاعمال-

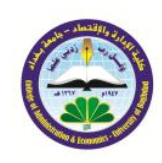

استراتيجيات ادارة الموارد البشرية .

PAdu|

|

المجلد 20

العدد VA

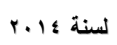

الصفحات 1-9نة r ب r 


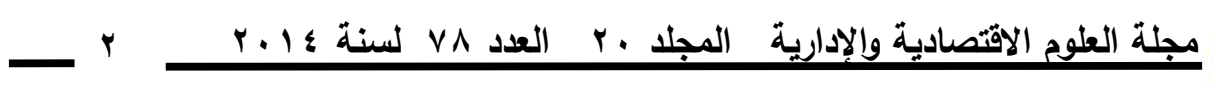

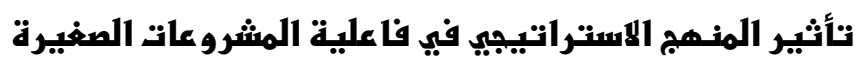
والمتوسطة في العراق - بـثث ميدانيي

\section{المور الاول/ منهجية البحث}

سيتم في هذا المحور تناول مشكلة البحث واهميته واهد(فه ونموذجه وفرضياته وادواته وكالاتي: اولا: مشكلة البحث

تبرز مشكلة البحث على المستوى النظري من حيث الجدل الحاصل حول توظيف ادارة الموارد البشرية بما يكفل تحقيق نجاح فاعلية المشروعات وعلاقة استراتيجيات الاعمال معها ، والجدل حول النتائج المتوقعة لهذا تونات التوظيف ، واما على الصعيد الميداني للتطبيق ، أذ تبدو المشكلة في مدى تمكن المديرين من توظيف الموارد

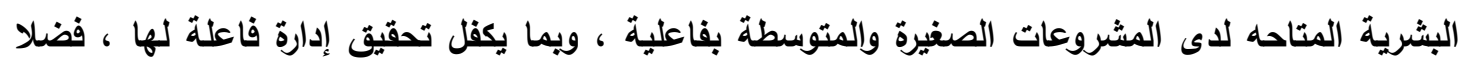
عن استنباط أفضل الأساليب الادارية والتحفيز والمحافظة على العاملين لايهم.

ثانيا: الهمية البحث

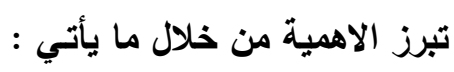
1. أهمية المشروعات الصغيرة والمتوسطة في تطوير وظائف جديدة ، وتقليل مستويات البطالة لخدمة المجتمع العراقي . المبه المثرعان r. يمثل البحث محاولة لإقتاع قادة المشروعات الصغيرة والمتوسطة (مالكين و مديرين) بالاهتمام بالمورد

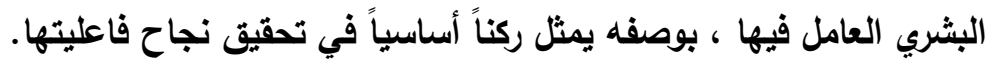

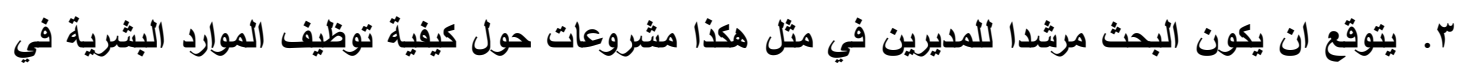

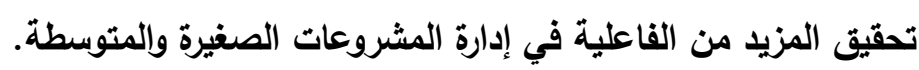

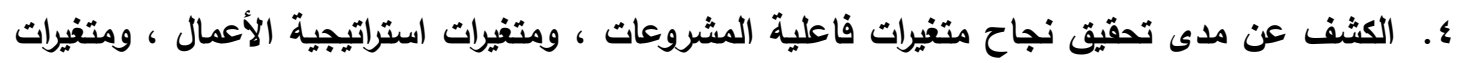

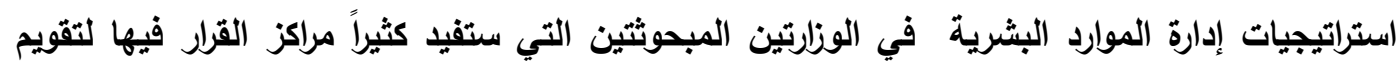
مستوى الأداء للمشروعات المتبناة والإفادة منها في تحقيق التقام المنشود في إطار معيار الفاعلية التنظيمية ثالثا: اهداف البحث يسعى البحث الحالي الى بلوغ الاهداف الاتية : 1. تثخيص مستوى فاعلية الأداء في المشروعات المدروسة كحالة تطبيقية على مستوى العراق ، فضلاً عن تقييم المتغيرات المدروسة الثلاثة لموضوع الاراسة المتمثلة بإستراتيجيات الأعمال واستراتيجيات إدارة الموارد البشرية في تحقيق هذه الفاعلية في ضوء تحليل استجابات أصحاب المشاريع للحالة الدراسية التي تعكس واقع المتغيرات الثثلاثة إلى حد كبير. r. تحديد طبيعة العلاقة ومستوى الثأثير للموارد البشرية في تحقيق نجاح فاعلية أداء المشروعات الصغيرة والمتوسطة ، وذلك وصولآ لمحاولة التوصل إلى معايير ومتطلبات ومؤثرات قد تسهم في تلافي السلبيات ، وتحفيز أصحاب المشروعات الصغيرة والمتوسطة للعمل بثكل أفضل من خلال تعزيز الايجابيات واستثمارها لصالح تحقيق فاعليتها المنشودة ومن خلال اتباع المدخل الاستراتيجي في إدارة الموارد 


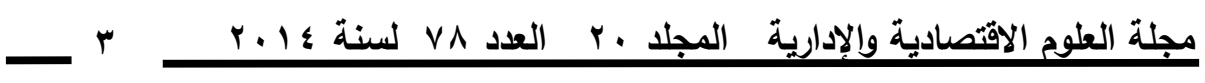

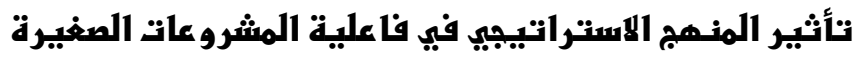

والمتوسطة في العراق - بـهث ميدانيي

$$
\text { رابعا: فرضيات البحث }
$$

1. الفرضية الرئيسة : تتأثر فاعلية المشروعات الصغيرة والمتوسطة بالعلاقة بين استراتيجيات الاعمال

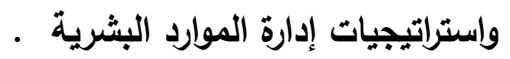

r. الفرضية الرئيسية الاولى: توجد علاقة ايجابية ذات دلالة معنوية بين استراتيجيات الاعمال

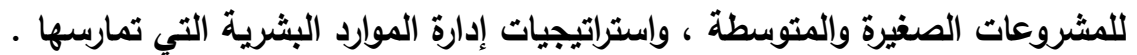

r. الفرضية الرئيسة الثانية : تتأثر فاعلية المشروعات الصغيرة والمتوسطة باستراتيجيات الاعمال بثكل

أكثر من استراتيجيات إدارة الموارد البشرية التي تتبناها

خامسا: المخطط الفرضي للبحث

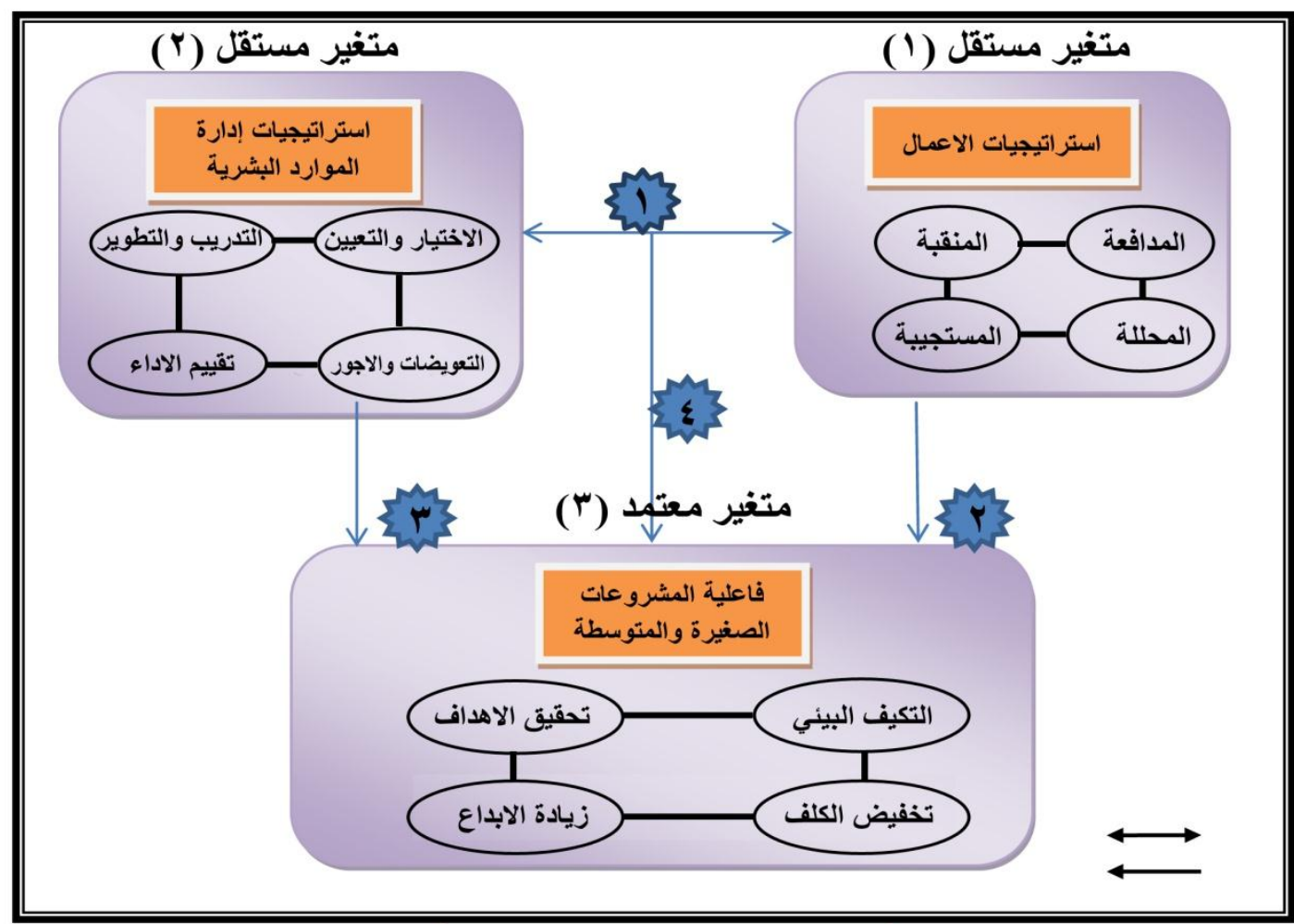

الشكل(1) المخطط الفرضي للبحث (من اعداد الباحثة)

سادسا :الاساليب الاحصائية

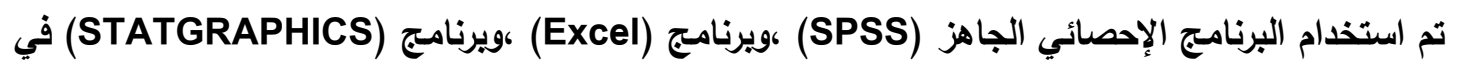
إدخال بيانات البحث وتحليلها ، ومن أهم الأدوات الإحصائية التي تم استخدامها في الجاتب الميداني لهنئ

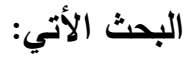

ا. التوزيع التكراري (Prequencies) والنسب المئوية (Percentages) لعرض البيانات الخاصة باختبار

عينة البحث ووصفها.

r. الوسط الحسابي (Mean) وهو احد مقاييس النزعة المركزيه ويستخدم لمعرفة مستوى كل متغير. r. الانحراف المعياري (Standard deviation) لحساب قيمة معامل الاختلاف عن طريقهما، ومعرفة مستوى كل متغير ودرجة التشتت في القيم عن وسطها الحسابي. 


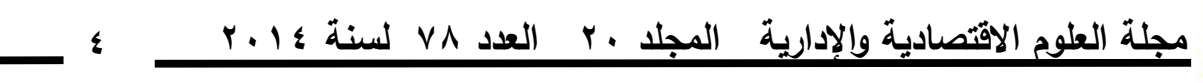

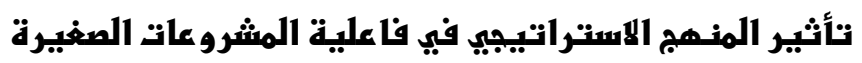

$$
\text { والمتوسطة في العراق - بـثث ميدانيي }
$$

ع. معامل الارتباط القويم Canonical Correlation) لغرض إثبات أهمية المتفيرات وأسبقياتها . ๑. معامل الاختلاف المطلق Coefficient of Variation) لتحديد الانسجام النسبي الأكثر تجانساً على وفق إجابات العينة .

ד. معامل ارتباط بيرسن براون (pearson-Brown Correlation Coefficient) لقياس نوع العلاقة

$$
\text { ودرجتها مابين متغيرات البحث و لقياس معامل الصدق وإلثبات للاستبانة . }
$$

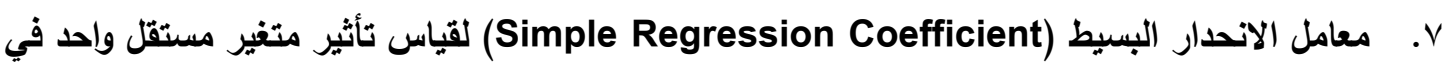

متغير معتمد واحل .

^. معامل الانحدار المتعدد) Multiple Regression Coefficient) لقياس تأثير عدة متغيرات في معدي

$$
\text { متغير معتمد واحد. }
$$

9. تحليل المسار (Path-Analysis) لقياس التأثير المباشر وغير المباشر والكلي للمتغير المستقل في

$$
\text { المتغير المعتمد من خلال متغير وسيط . }
$$

• (. أختبار (f) : لأختبار معنوية معامل نماذج الانحدار البسيط ، واستخدام طريقة (ألفا كرونباخ) لتحديد

$$
\text { سابعا : عينة البحت الاستبانة }
$$

تضمن عينة البحث اختيار عينة عشوائية مكونة من ( ( . (1) شخص من المديرين والموظفين المسؤولين عن هذه المشروعات ومديري اختصاص هذه المشروعات في وزارتي التخطيط والعمل والثؤون من من

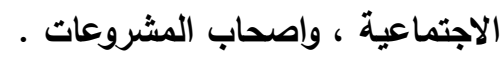
ثامنا : الصدق والثبات استعملت طريقة التجزئة النصفية (Split Half) لقياس الثبات وتعتمد على إيجاد معامل الارتباط بين درجات الأسئلة الفردية وبين الأسئلة الزوجية في الاستبانة، ويتم تصحيح معامل الارتباط بمعادلة سبيرمان

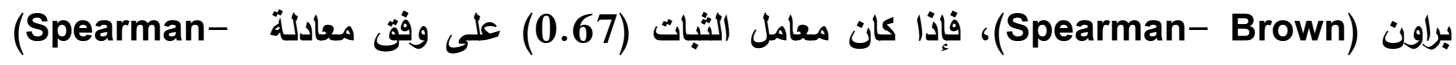

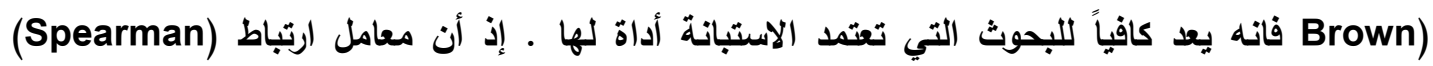
لنصف الاستبانة (0.69) ويعد أن تم تصحيحه بمعادلة (Spearman- Brown) فأصبح معامل الثبات الاستبانة ككل (0.82) هذا يعني أن استبانه البحث بمقاييسها المختلفة ذات ثباتٍ جيد ويمكن استخدامها في

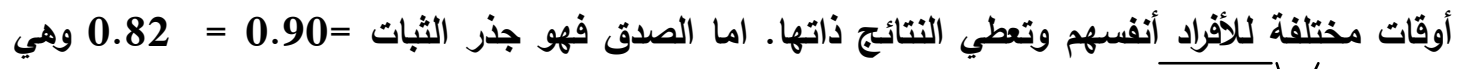

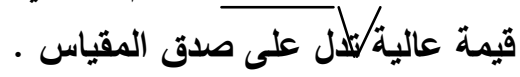




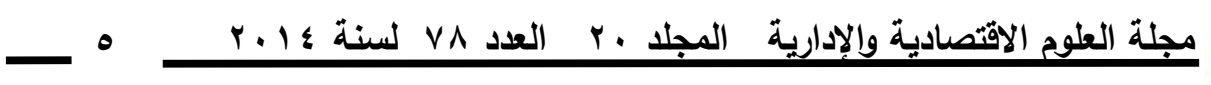

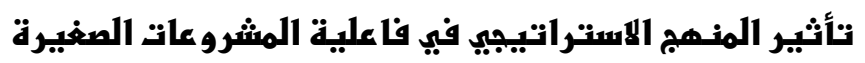
والمتوسطة في العراق - بـهث ميدانيي كئي

\section{المحور الثاني \الجانب النظري المبري}

سيتم في هذا المحور تناول المفاهيم الاساسية للمشروعات الصغيرة والمتوسطة وفاعليتها ، واستراتيجيات الاعمال ، واستراتيجيات ادارة الموارد البشرية فئماول

\section{اولا: المشروعات الصغيرة والمتوسطة}

سيتم في هذه الفقرة عرض مفهوم المشروعات الصغيرة والمتوسطة واهميتها ومعايير تصنيفها وفاعليتها.

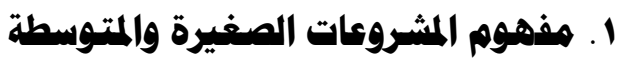

المشروعات الصغيرة والمتوسطة يمكن أن يتم إيضاحها بطرق مختلفة ويمكن أن يتم تصنيف الأعمال

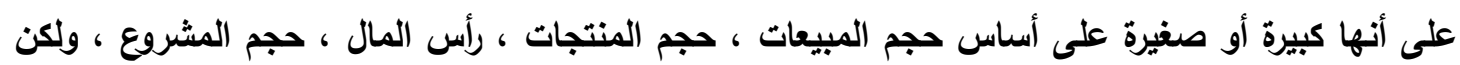

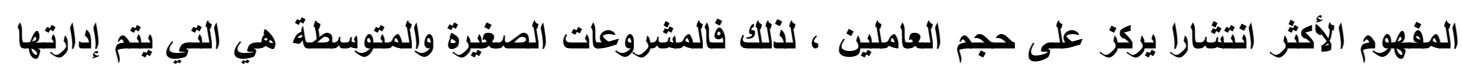
بأقل من خمسين عاملا أو الأعمال التي تتم إدارتها من قبل مالك المشروع ، وأن الأعمال التي يتم إدارتها

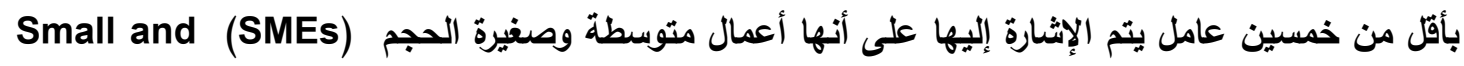
(Schrier\&Hallin\&Johnson,2005: 4) Medium Enterprises الصغيرة والمتوسطة عنصرآ مهما في وضع البرامج والسياسات ، ولكنها لابد ان توضع وتعد وفقآ لظروف كل

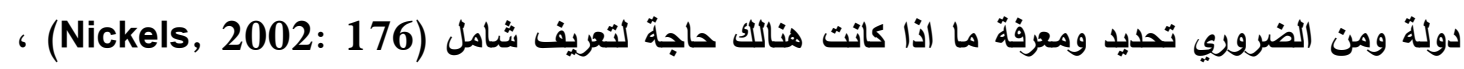
وإشارت ( العطية ، 2009 :15) ، بأنها تلك المشروعات التي تستخدم عددآ قليلآ من العاملين وتدار من قبل المالكين وتخدم السوق المحلية . تتبع أهمية المشروعات الصغيرة والمتوسطة كوسيلة فاعلة لزيادة الانتاج وتخفيض الكلف وان التطور

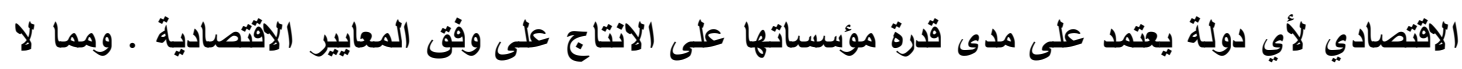

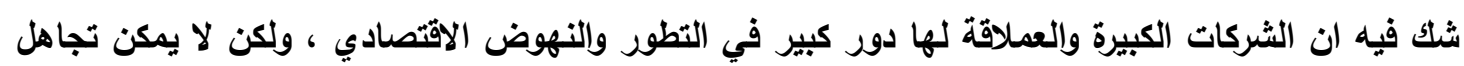
دور المشروعات الصغيرة ومدى مساهمتها بصرف النظر عن درجة تقدمها وخاصة الدور الذي تلعبه في

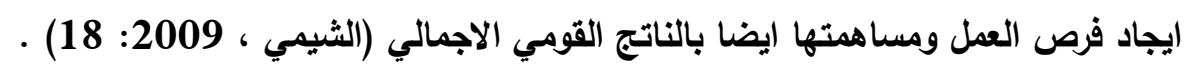
r معايير تصنيف المشروعات الصغيرة والمتوسطة

أثثار البعض ان بعض الدول تصنف المشروعات الصغيرة والمتوسطة بحسب معيار الموجودات والبعض بحسب المبيعات اي العوائد السنوية وأخر على أساس العمال وأصحاب المصالح في حين صنفها البعض الهض الأخر على أساس عدد العاملين والذي يضم (9) عاملين في المشروعات المصغرة و(49) عاملا للمشروعات الصغيرة و(250) عاملا للمشروعات المتوسطة ، ويأخذ بنظر العناية معيار دوران العمل وإجمالي الميزانية

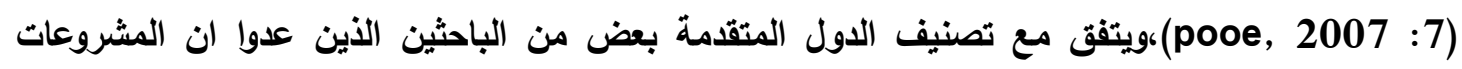

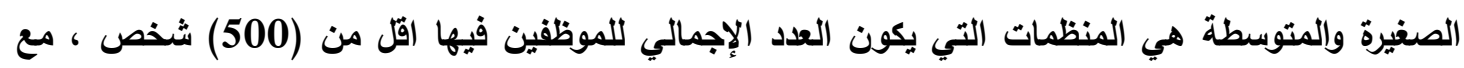

$$
\begin{aligned}
& \text { التقسيمات الفرعية الآتية : }
\end{aligned}
$$

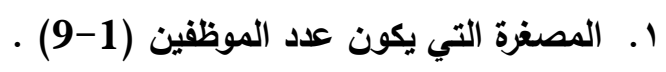

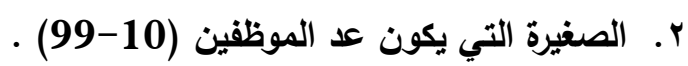

$$
\begin{aligned}
& \text { r. المتوسطة التي يكون عدد الموظقين (100-499) . }
\end{aligned}
$$




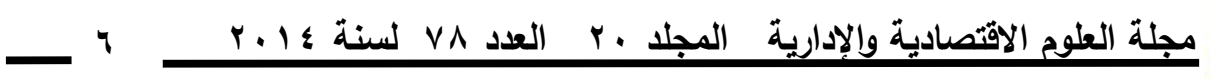

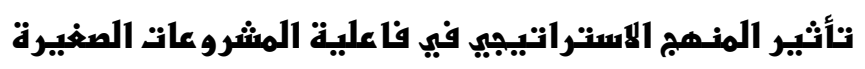
والمتوسطة في العراق - بـهث ميدانيي

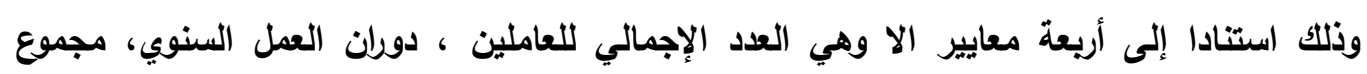

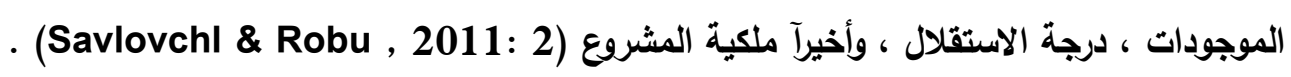

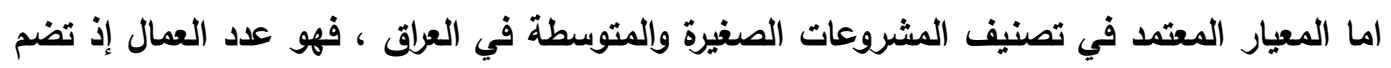

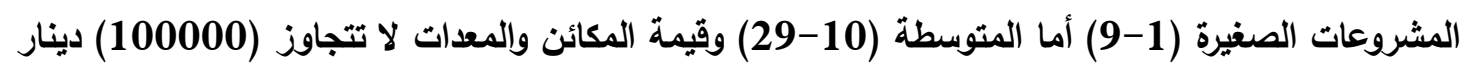

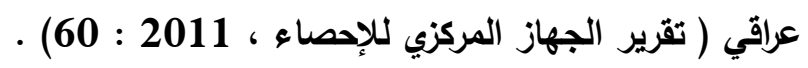

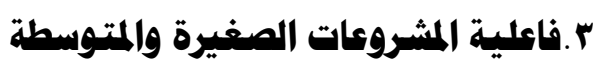
تنبع أهمية قياس فاعلية المشروعات من تزايد أهميتها فى الوقت الحاضر ، فقد بدأت هذه المشروعات

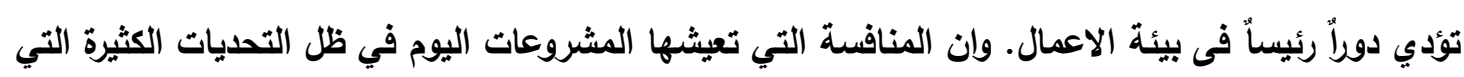

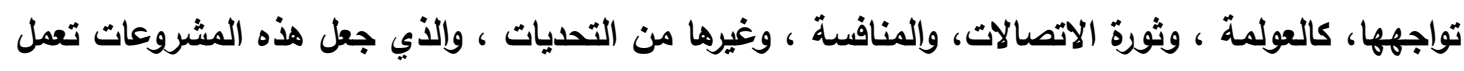

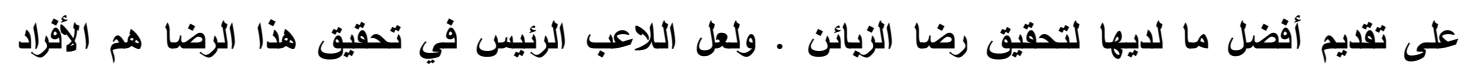

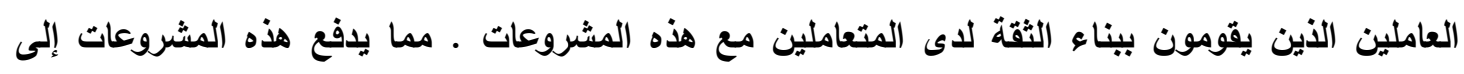

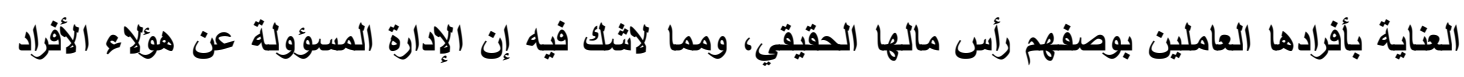

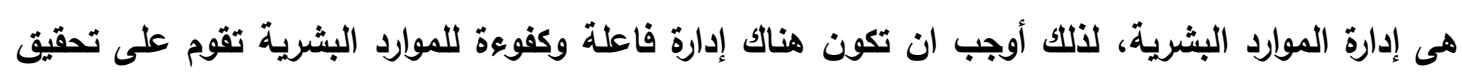

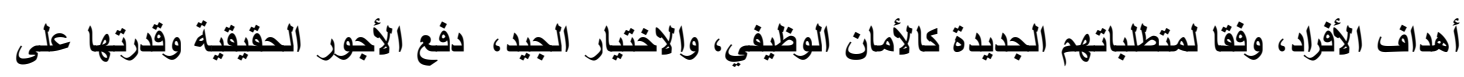

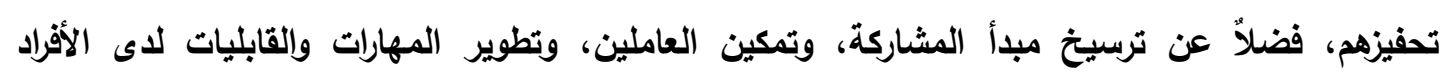

.(Ivanecivich, 1997;658)

\section{ع. همسايير فاعلية المشروعات الصغيرة والمتوسطة}

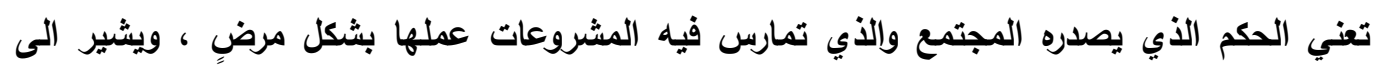

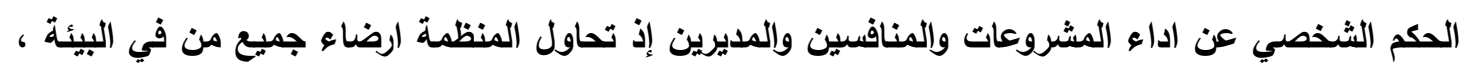

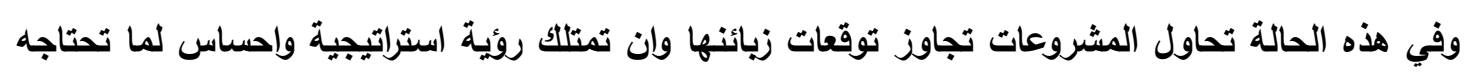

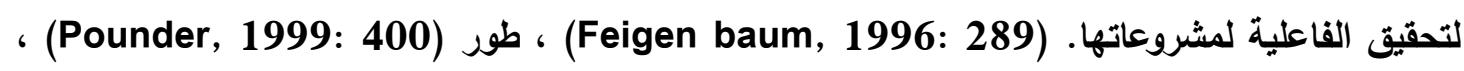
(Robbins,2003) أ. التكيف البيئي : قدرة المنظمة على التوائم مع متغيرات الداخلية والخارجية للسوق من خلال قدرتها على تلبية حاجات الزيائن الحاليين والمحتملين ، وتوقع المشكلات التي تواجهها في المستقبل .

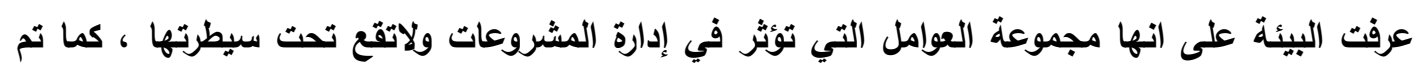

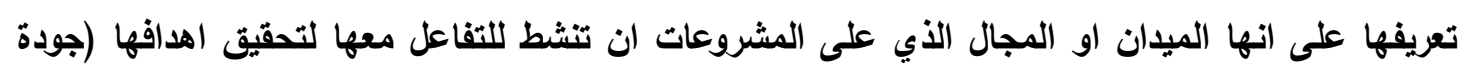
وآخرون ، 19:2012) • وعرف (12: Van Gundy,2005) التكيف هو استجابة المشروعات للتغير والسياسات التي تضعها لمواجة تلك الجواتب المتغيرة في علاقاتها مع بيئتها ومحيطها الخارجي ، واوضح

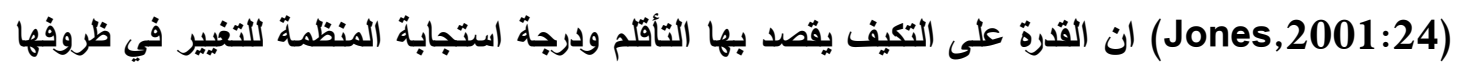
الاخلية والخارجية عن طريق حصولها على معلومات عن التغييرات والتقلبات الحادثة في البيئة . 


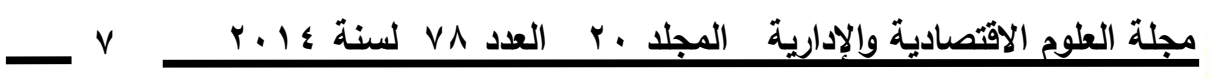

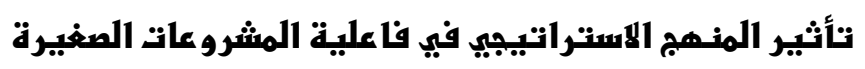
والمتوسطة في العراق - بـهث ميدانيي

ب. تحقيق الاهداف : يبين مدى قدرة المنظمة على وضع الاهداف وتحقيقها وتثبير الى سهولة الاستعمال

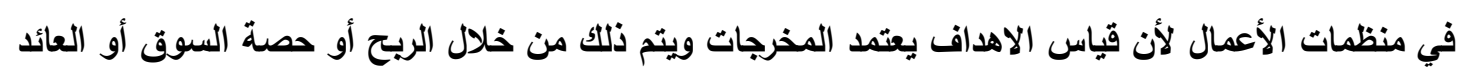

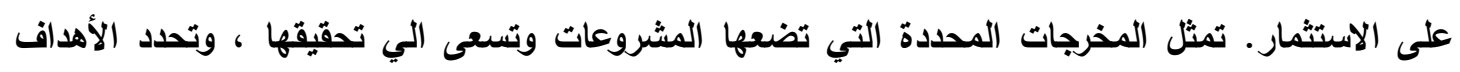

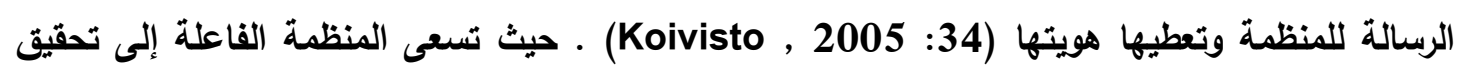

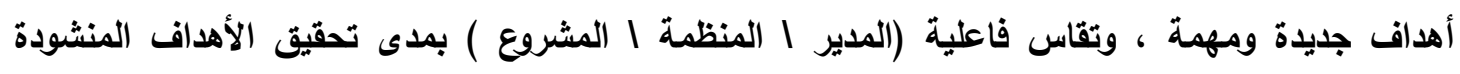

(Marion \& Mari , 2006 :12)

ج. تخفيض الكلف : وهو الاليل والمؤشر على تحسين الكفاءة ، بأفتراض المحافظة على نوعية المخرجات

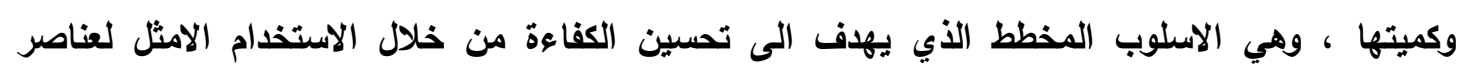

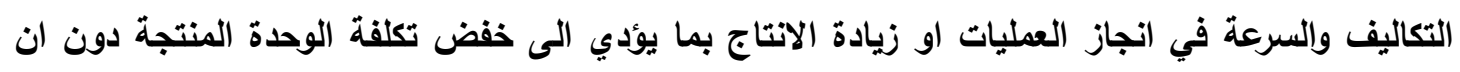

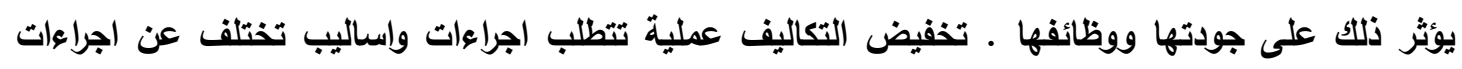

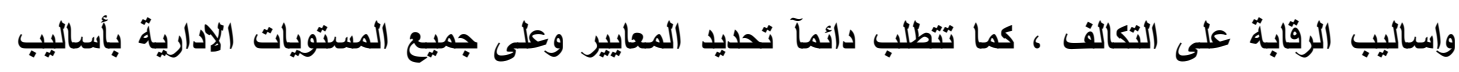

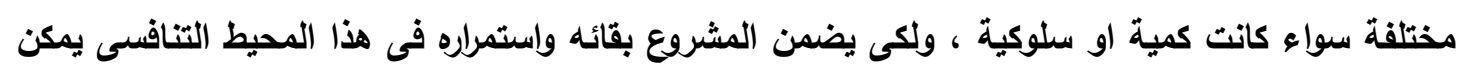
أن يتبع اساليب واستراتيجيات مختلفة منها تخفيض الكلف حيث انه سيعمل على جعل أدائه يفوق أداء منافسيه فى إنتاج المنتجات أو الخدمات بأقل تكلفة ومن ثم الحصول على أرابح مستديمة بأقل الأسعار وهذا

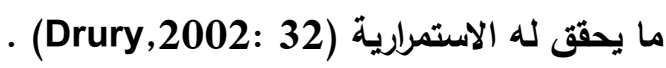

د. زيادة الابداع : تعد عملية زيادة الابداع نتيجة مستمرة نسبة للتطورات الأساسية والثانوية ، فأن أفكار جليدة

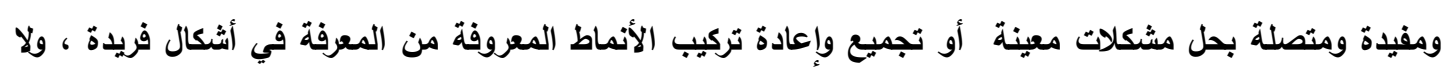

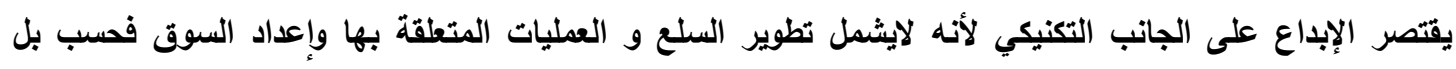

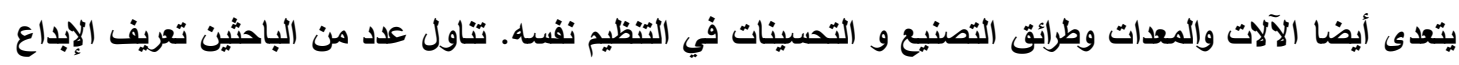

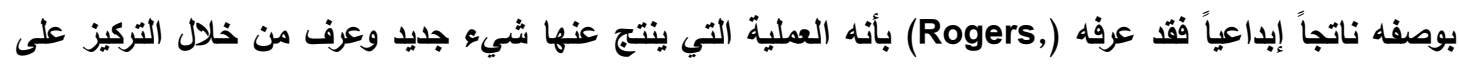

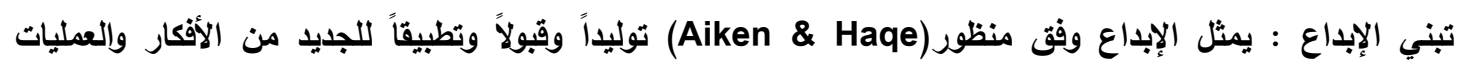

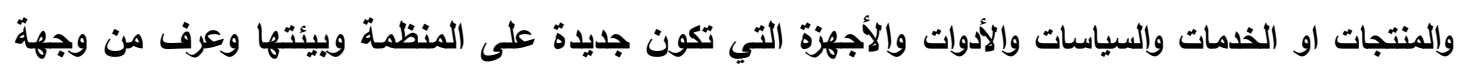

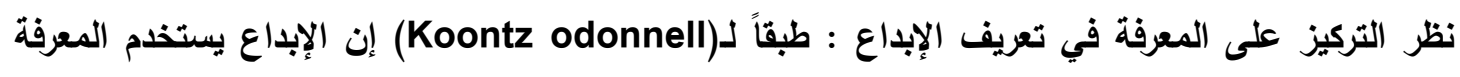

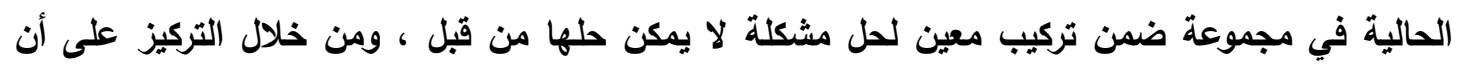

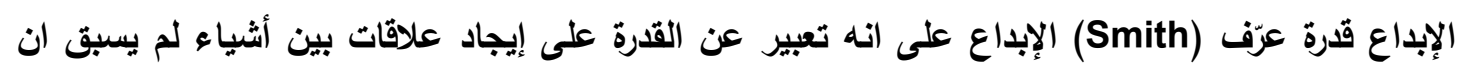

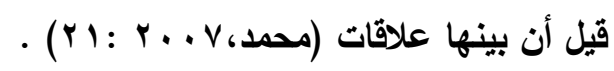

ثانياً : استزاتيجِيات الاعمال سيتم في هذه الفقرة عرض مفهوم استراتيجيات الاعمال وانواعها

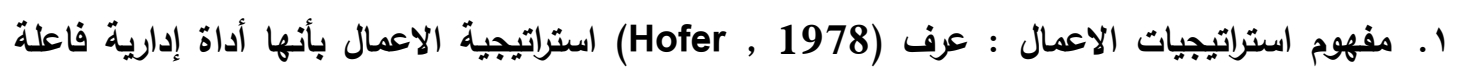

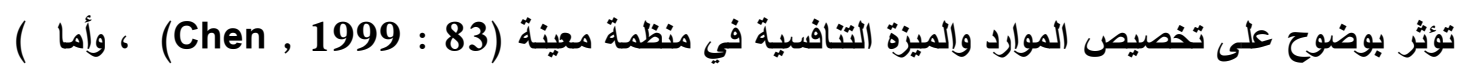

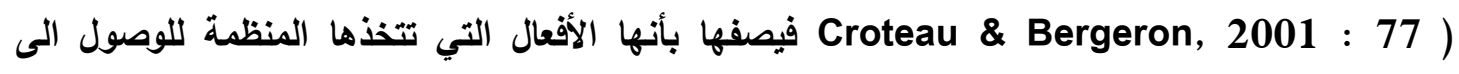
أهدافها ، وقد أثنار ( 54 : Thompson, 2003 ) ان المفهوم الأساسي لاستراتيجية الأعمال هي تختص باتصال

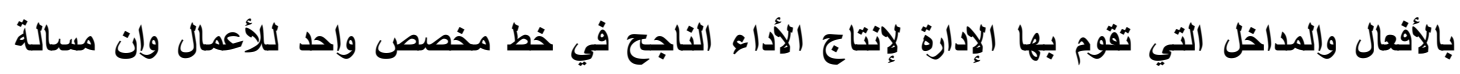

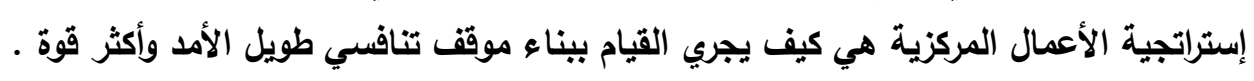




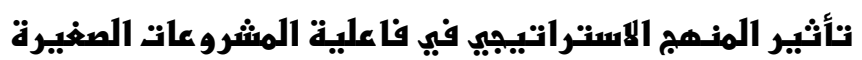
والمتوسطة في العراق - بــث ميداني

r. أنواع استراتيجيات الاعمال :

التي تم اختيارها وفق انموذج ( Miles \& Snow ) حيث صنف الاستراتيجيات الى اريعه انواع وكما يأتي:

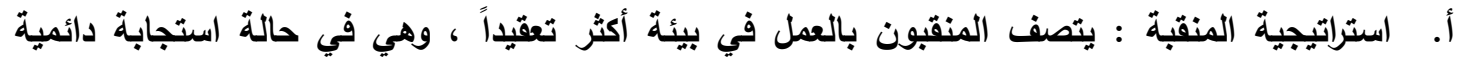

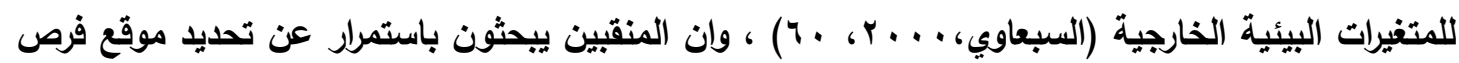
المنتج والسوق الجديدة واستغلالها ( 5 : Apigian , et al , 2002 ) . والمشروعات تقريباً تبحث باستمرار عن فرص السوق ، وأنها تقوم بانتظام بتجرية الاستجابات الممكنة الى الاتجاهات البيئة الظاهرة

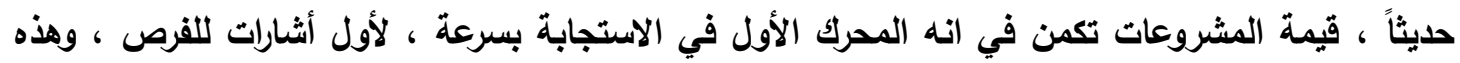
الاستجابات غالياً تقوم على فعل تنافسي ، لهذا يكون هناك منطلب منهم هو امتلاكهم قاعدة تسويقية وتقنية

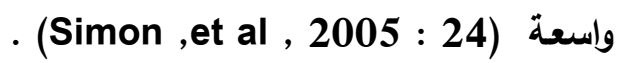

ب. استراتيجية المدافعة : يميل المدافعون إلى العمل في بيئة مستقرة ، وهم يحاولون عزل جزء من السوق الكلي

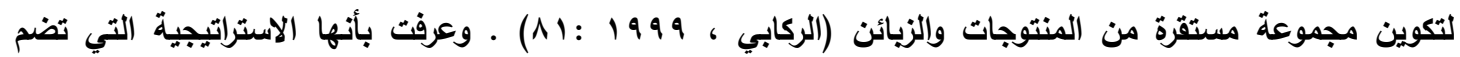
مجالات المنتج / سوق ضيقة ( Gimenez, 1994 : 4 ) ، وتحاول هذه الاستراتيجية تحديد موقع امين والمحافظة عليه (Benedett, Song, 2003 : 517) ج. استراتيجية المحلة : تقع هذه الاستراتيجية في منتصف الاستراتيجيتين المتعاكستين (المدافعة والمنقبة) حيث تهاف

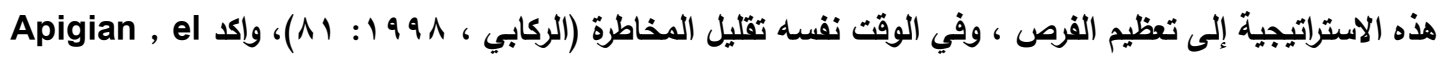
(at , 2002 : 3 ) يكونوا بصورة اعتيادية الثاني الذي يدخل سوق / منتج جديد بعد الاخول الأول للمنقبين .

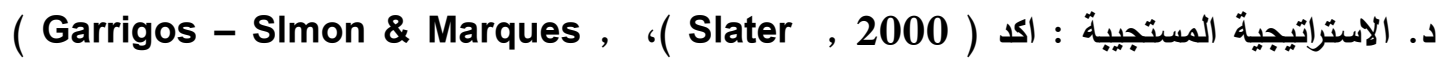

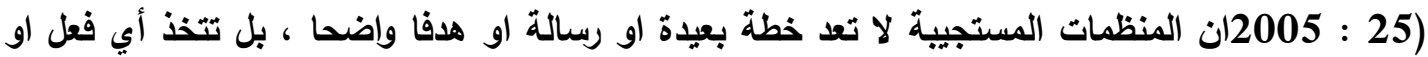
سلوك لتلافي الحاجات آلانية ، كما اضاف ( Benedett \& Song , 2003 : 518 ) أنهم ليس لديهم استجابة منسجمة مـع مشكلة الاستثمارية انها بقايا استراتيجية ، ومن ثم يستجيبون عندما يشعرون بانهم مضطرون للاستجابة بسبب الضغوط البيئة ، ويالرغم من ان الاستراتيجية المستجيبة تكون ناجحة في بعض لهض الأحيان فانها يمكن ان تؤدي الى فشل المنظمة في أحيان أخرى . ثالثاً : استراتيجيات ادارة الموارد البشرية سيتم في هذه الفقرة تعريف استراتيجيات ادارة الموارد البشرية وانواعها

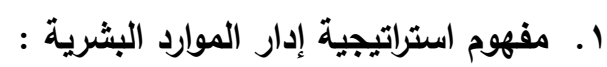

ان المدخل الاستراتيجي لادارة الموارد البشرية يبحث عن الفعل المسبق الفاعل الذي يوفر الميزة التنافسية للمنظمة

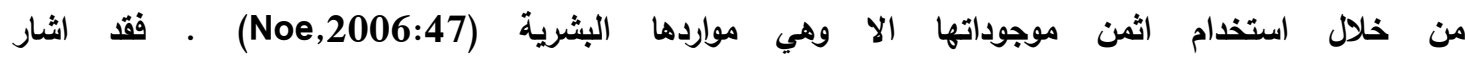
(Gratoon, 2000 : 26 )

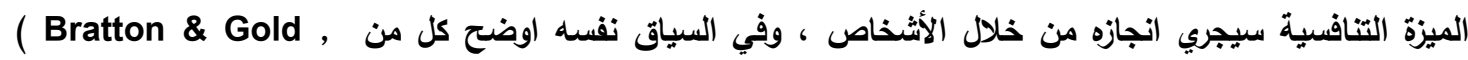
(122) 2003 : 122 إذا كاتت هناك موارد غير بشرية متماثلة ومتوافرة لاى المنظمات المتنافسة متمثلةً بالمواد الأولية والمصانع والتكنلوجيا والعدد والآلات ، فان الاختلاف فيما بين هذه المنظمات يجب ان ينسب إلى اختلافات الاداء بين

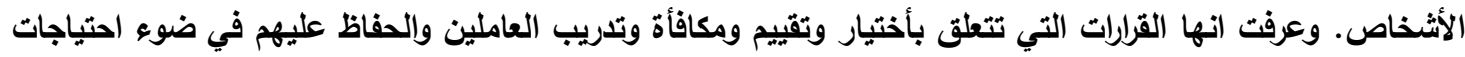


r.استراتيجيات ادارة الموارد البشرية لقد تم اختيار هذه الاستراتيجيات لتلبي متطلبات البحث الحالي :

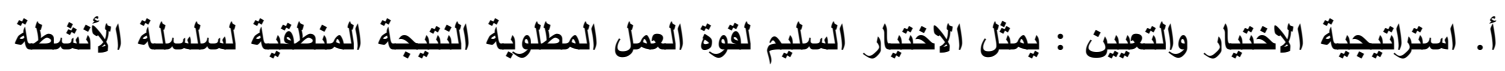

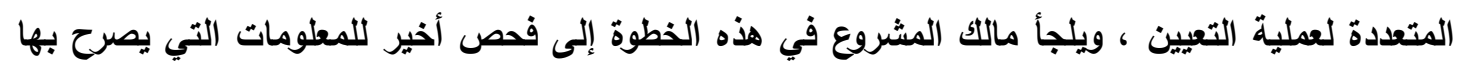

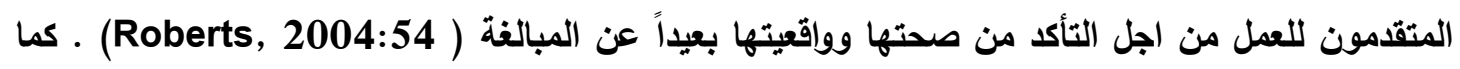

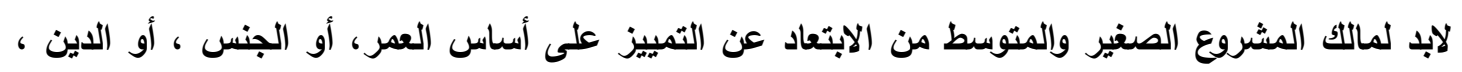

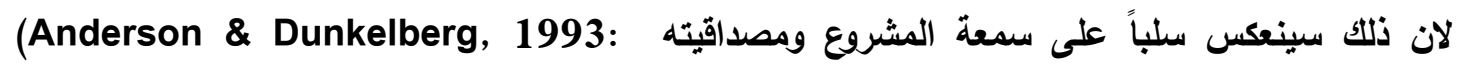
(244. وقد رأى (Noe,et al, 2006: 70) ان الاختيار علية التي تحاول من خلالها المنظمة تحديد

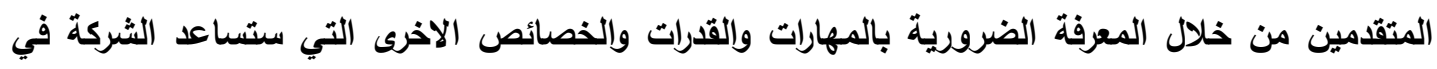
تحقيق اهدافها. تتولى إدارة الموارد البشرية إصدار أوامر التعيين وشغل الوظيفة بعد اجتياز مرحلة المقابلة

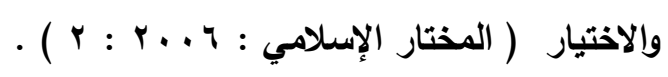
ب.استراتيجية التدريب والتطوير : يمثل المورد البشري أحد الموارد الأساسية التي تسهم في نجاح المشروعات

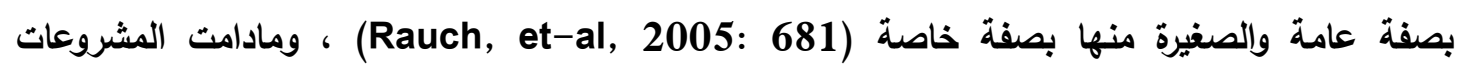
الصغيرة تواجه صعويات كثيرة في الحصول على المهارات المحدة والفريدة وايجادها لتحقيق أهدافها (Lepak \& Snell, 1999: 31)

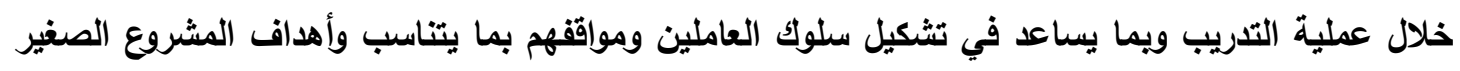
وطموحاته (Boxall \& Steeneveld, 1999: 443) ، وقد أثادت الكثير من الدراسات الى أهمية التدريب بوصفه واحداً من تطبيقات إدارة الموارد البشرية ذات التأثير الايجابي في تحسين أداء المشروعات

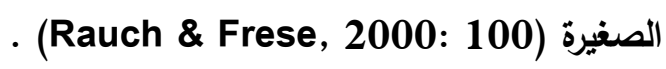
ج. استراتيجية التعويضات والأجور : التعويض احد التطبيقات المهمة لإدارة الموارد البشرية في المشروعات كافة

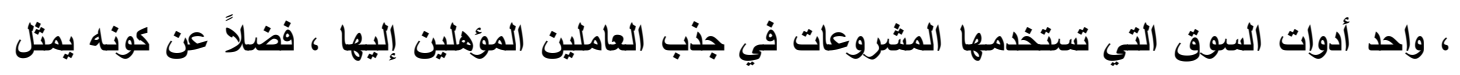

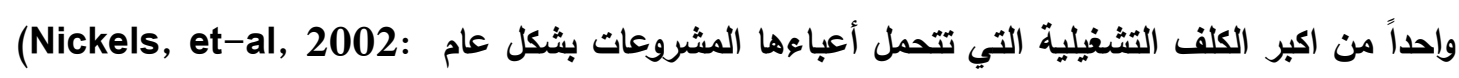
(344 ـ ويعد التعويض في الوقت الحاضر احد التحديات التي تواجهها المشروعات في ظل بيئة العمل المتسمة بالمنافسة الثديدة ، والتي تحتم على المشروعات العمل على خفض كلفها إلى أدنى مستوى ممكن

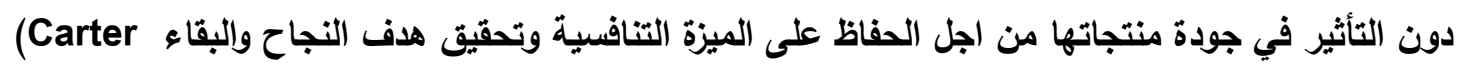
. \& Jones- Evans, 2000:309)

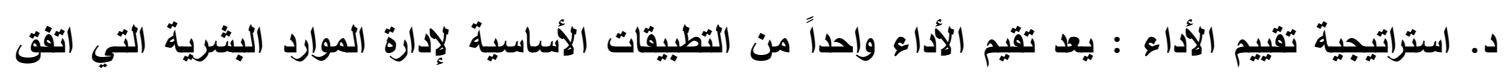

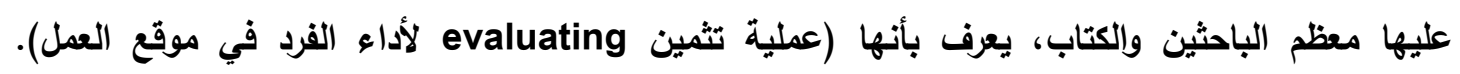

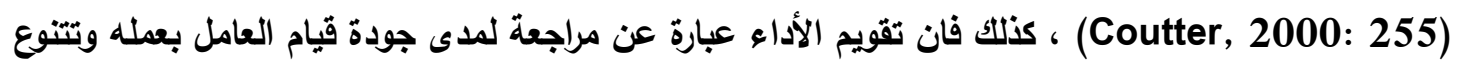

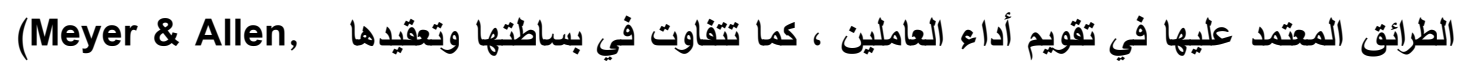

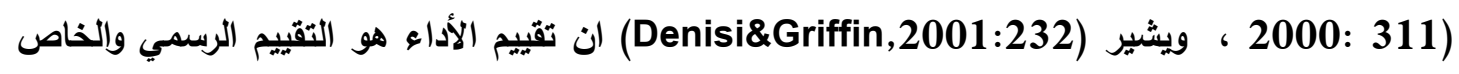

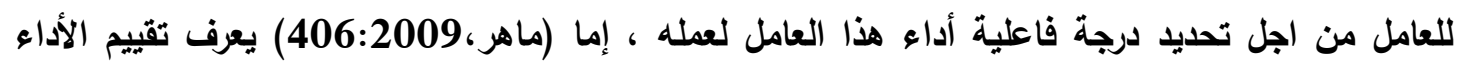

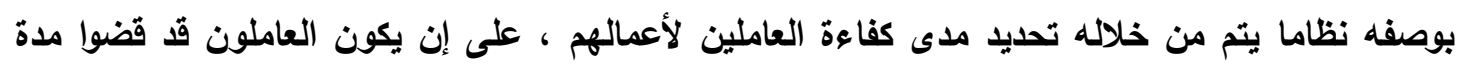
زمنية في إعمالهم. 


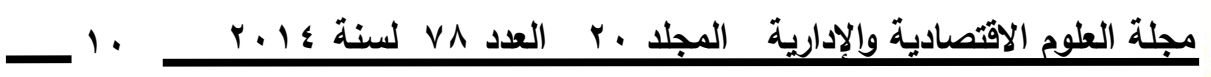

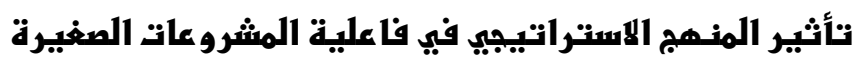
والمتوسطة في العراق - بـهث ميدانيي

\section{الحمور الثالث \عرض وتهليل النتائج واختبار الفرضيات}

سيتم في هذا المحور عرض وتحليل النتائج التي افرزتها الاستبانة لتشخيص مستوى متغيرات البحث بأستخدام بعض الاساليب الاحصاء الوصفي : الوسط الحسابي لتقدير مستوى كل متغير ، والانحراف المعياري

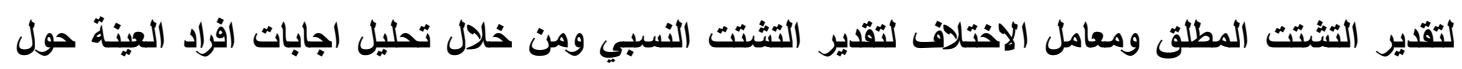

الابعاد المكونة لكل متغيرات البحث الرئيسية والفرعية ثم بعد ذلك اختبار فرضيات البحث وكألاتي : ا.استراتيجيات الاعمال: قيس هذا المتغير من خلال أريعة ابعاد فرعية هي (المدافعة ، المنقبة ، المحللة ،

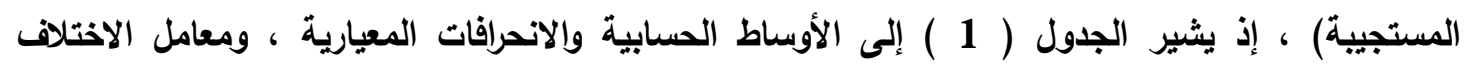

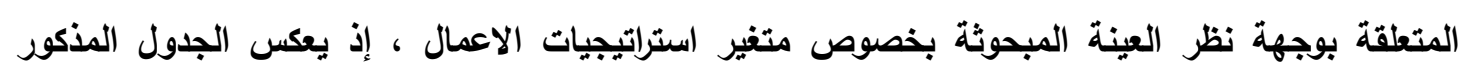

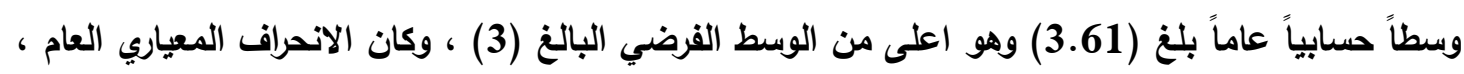

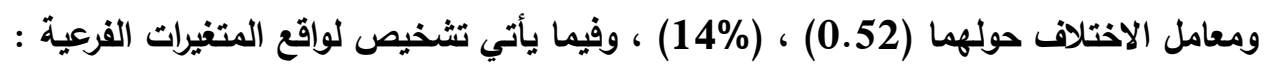

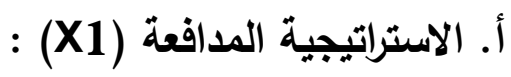

حقق هذا البعد وسطاً حسابياً عاما بلغ (3.54) حول الوسط الفرضي ، وكان الانسجام ذو تثتت فوق

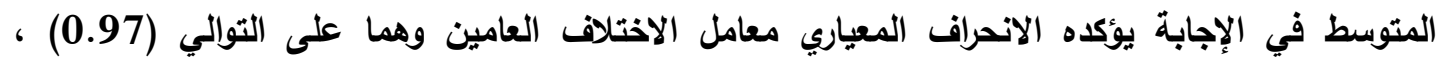

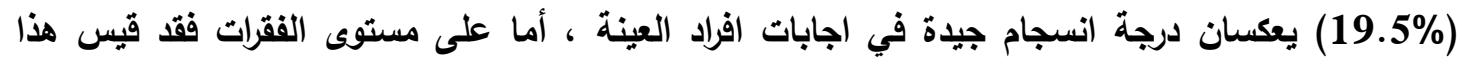

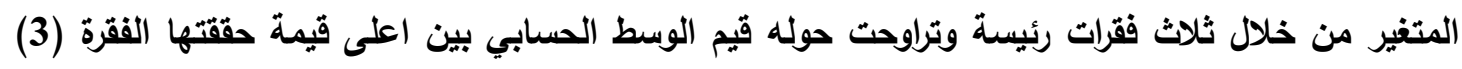
بلغت (3.87) ، وهي حول قيمة الوسط الفرضي ويتثتت عالي في الاجابات يؤكده الانحراف المعياري ومعامل

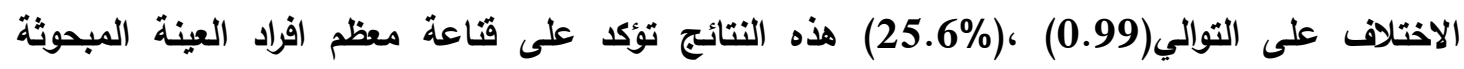

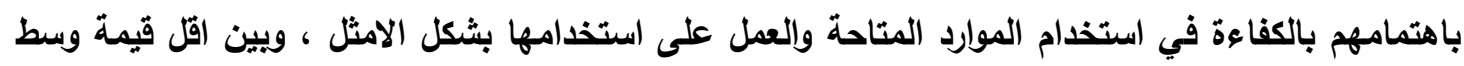
حسابي حققتها الفقرة (1) ، اذ بلغت (3.3) ، ويتشتت في الاجابات اذ بلغ الانحراف المعياري و معامل الاختلاف على التوالي (1.37) ، (41.6\%) وتدل هذه النتائج على علم تركيز المشروعات المبحوثة لعينة البحث على جزء صغير من السوق بل تتعدى ذلك من وجهة نظر عينة البحث . ب. باستراتيجية المنقبة (X2)

يشير الجدول (1) وسطا حسابيا عاما لهذا البعد فوق الوسط الفرضي، إذ بلغ (3.93)، بانسجام جيد في

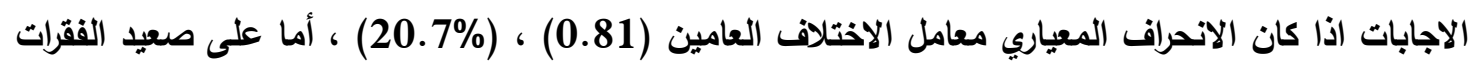
فقد قيس هذا البعد من خلال(3) فقرات ، وكانت النتائج حوله قد توزعت بين أعلى مستوى إجابة وقد حققتها

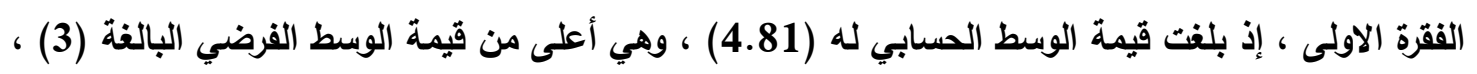

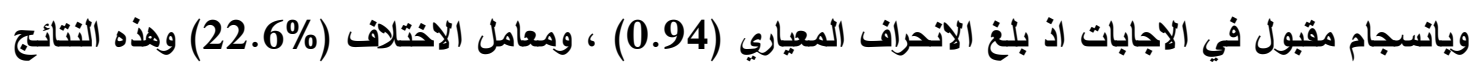
تلال على رغبة صاحب المشروع على البحث بأستمرار على فرص لاخول للاسواق العالمية من خلال البحث الائل

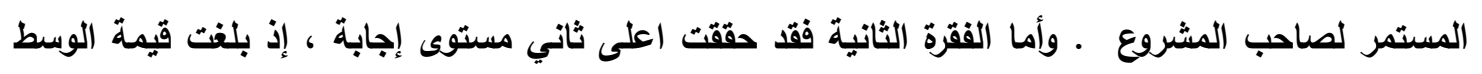

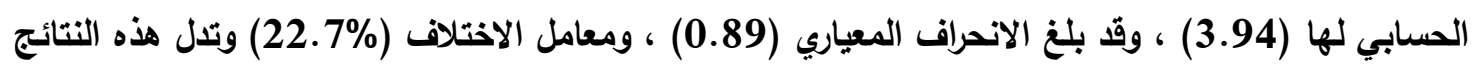

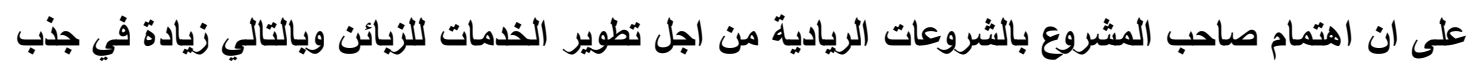

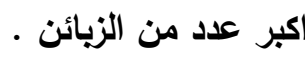




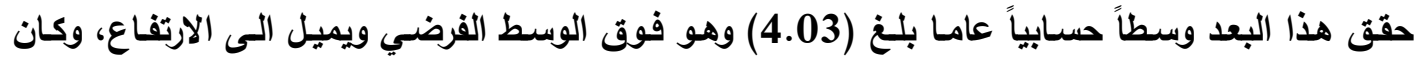

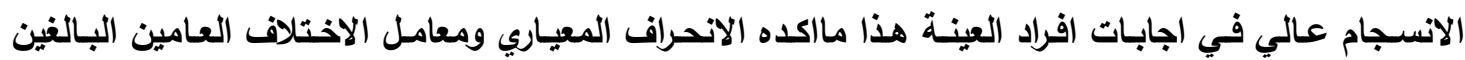

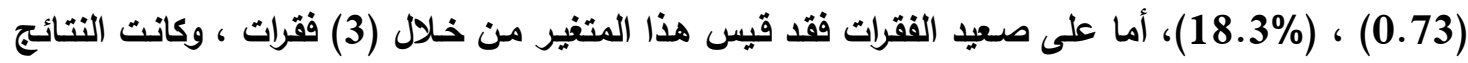

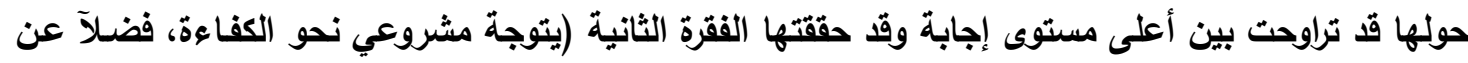

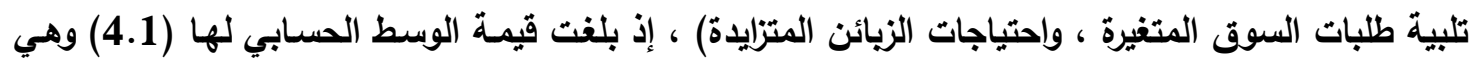

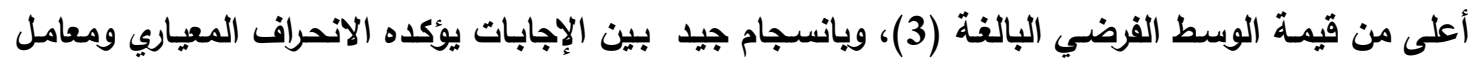

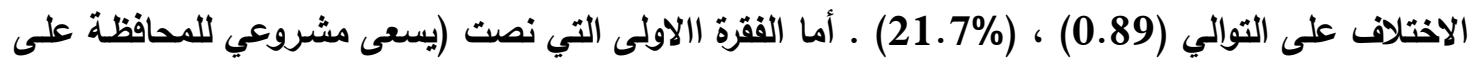

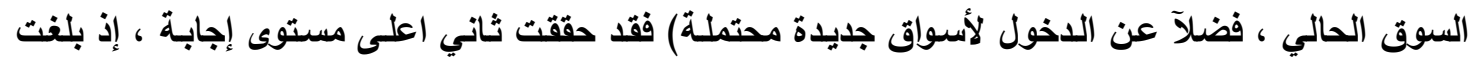

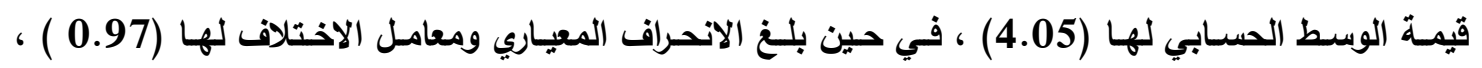

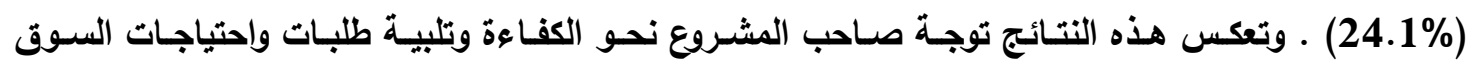

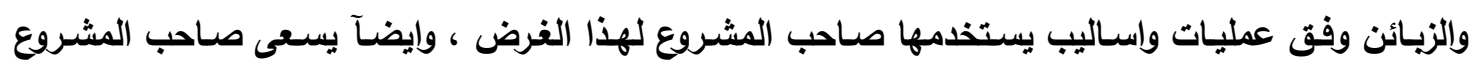

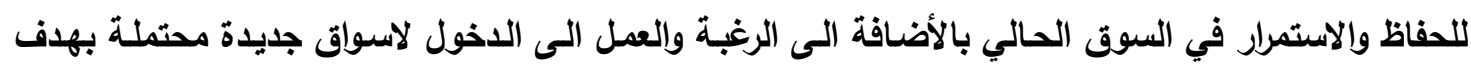

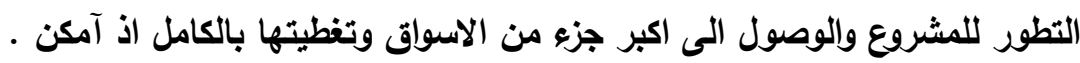
د. الاستراتيجية المستجيبة(X4) :

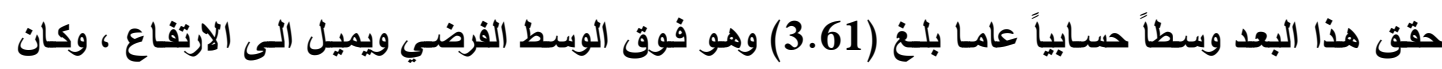

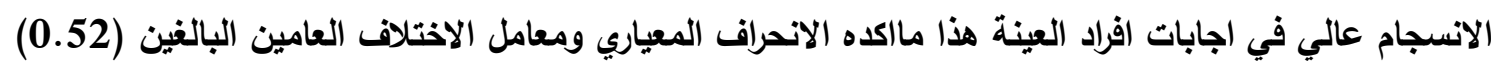

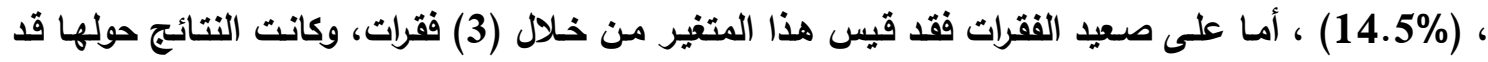

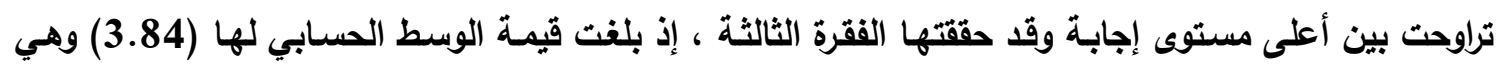

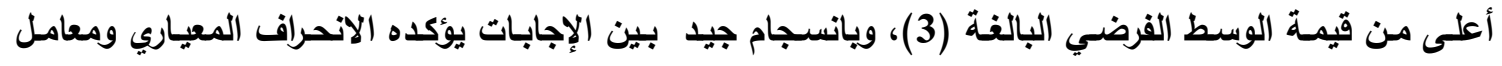

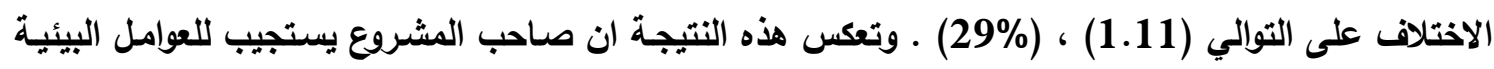

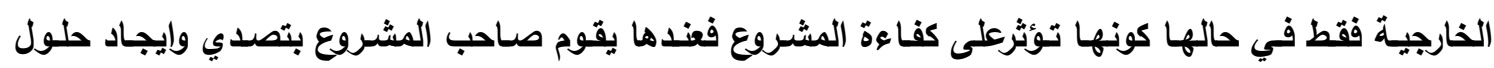

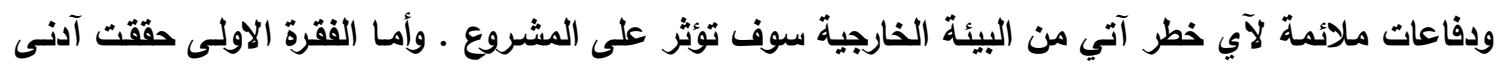

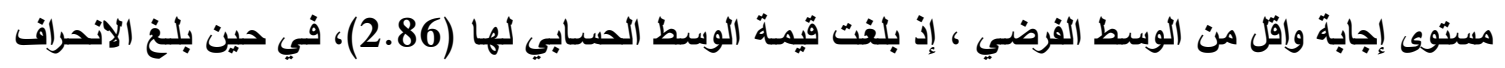

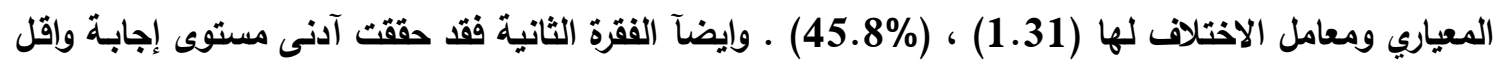

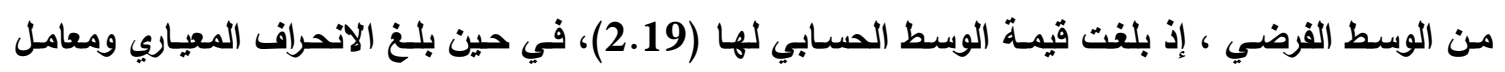

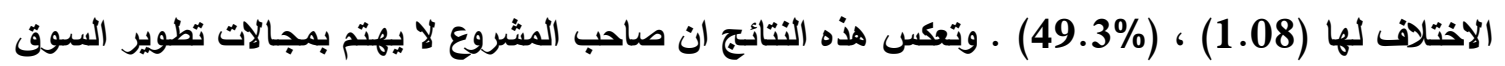

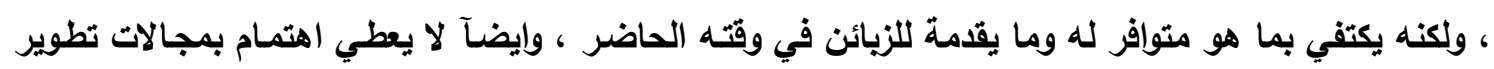

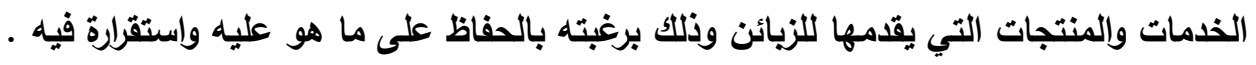




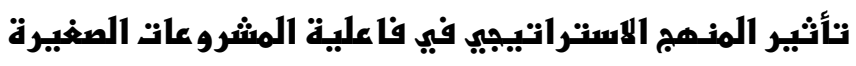 \\ والمتوسطة في العراق - بـهث ميدانيي}

N=100 جدول (1) الوسط الحسابي والانحراف المعياري ومعامل الاختلاف للاستراتيجيات الاعمال

\begin{tabular}{|c|c|c|c|c|c|}
\hline 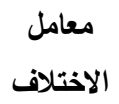 & 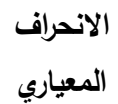 & الوسابي & 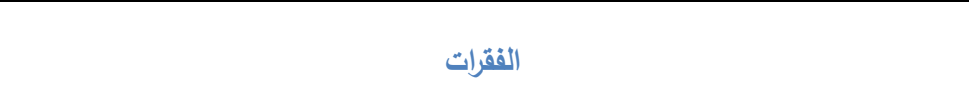 & \multicolumn{2}{|c|}{ 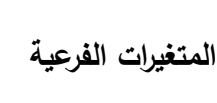 } \\
\hline 41.63 & $\begin{array}{c}1.37 \\
4\end{array}$ & 3.30 & يركز مشروعي على جزء صغير من السوق . & 1 & 武 \\
\hline 35.92 & 1.243 & 3.46 & يهتم مشروعي بثكل كبير بالاستقرار النسبي للذدمات او المنتجات التي يقدمها ـ & 2 & $\sqrt[7]{7}$ \\
\hline 25.60 & 0.991 & 3.87 & يتوجة مشروعي نحو الكفاءة المرغوية في استخدام الموارد المتاحة & 3 & $\frac{7}{\sigma}$ \\
\hline 27.45 & 0.97 & 3.54 & الوسط والانحراف ومعامل الاختلاف العام & & \\
\hline 22.65 & 0.94 & 4.18 & ابحث كصاحب مشروع بأستمرار عن فرص السبق في دخول الاسوق الجديدة . & 4 & $\overline{x_{3}}$ \\
\hline 22.76 & 0.89 & 3.94 & اهتم كصاحب مشروع بالريادية في تطوير خدماتي للزيائن . & 5 & $\frac{3}{3}:$ \\
\hline 33.20 & 1.22 & 3.68 & انفق مبالغ كبيرة على البحث والتسويق بحكم توجه مشروعي نحو السوق . & 6 & $\frac{3}{8}$ \\
\hline 20.72 & 0.81 & 3.93 & الوسط والانحراف ومعامل الاختلاف العام & & 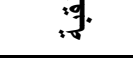 \\
\hline 24.14 & 0.97 & 4.05 & يسعى مشروعي للمحافظة على السوق الحالي ، فضلاً عن الدخول لأسواق جديدة & 7 & \\
\hline 21.78 & 0.89 & 4.1 & يتوجة مثروعي نحو الكفاءة، فضلآ عن تلبية طلبات السوق المتغيرة ، واحتياجات & 8 & $\overline{\overline{3}} \overline{3}$ \\
\hline 30.40 & 1.20 & 3.95 & يتوجة مشروعي نحو الكفاعة ، فضلاً عن تلبية طلبات السوق المتغيرة ، واحتياجات & 9 & \\
\hline 18.33 & 0.73 & 4.03 & الوسط والانحراف ومعامل الاختلاف العام & & \\
\hline 45.83 & 1.31 & 2.86 & لا يهمني التركيز على مجالات تطوير السوق ، بل اكتفي بما اقمه للزيائن في الوقت & $\begin{array}{l}1 \\
0\end{array}$ & \\
\hline 49.31 & 1.08 & 2.19 & لا اهتم كمالك للمشروع بمجالات تطوير الذدمات او المنتجات المقدمة للزبائن . & $\begin{array}{l}1 \\
1\end{array}$ & 率 \\
\hline 29.08 & 1.11 & 3.84 & استجيب لعوامل البيئة الخارجية فقط ، عندما تصبح مؤثرة في كفاءة مشروعي. & $\begin{array}{l}1 \\
2\end{array}$ & $\overline{\bar{z}}$ \\
\hline 28.14 & 0.83 & 2.96 & الوسط والانحراف ومعامل الاختلاف العام & & \\
\hline 14.54 & 0.52 & 3.61 & اجمالي الوسط والانحراف ومعامل الاختلاف العام & & \\
\hline
\end{tabular}

r.استراتيجيات إدارة الموارد البشرية: قيس هذا المتغير من خلال اريعة ابعاد فرعية هي (استراتيجية الاختيار والتعيين ، استراتيجية التدريب والتطوير ، استراتيجية الاجور والتعويضات ، استراتيجية تقييم الاداء)،

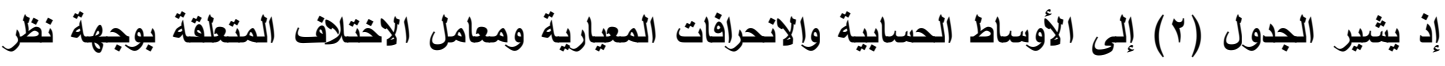

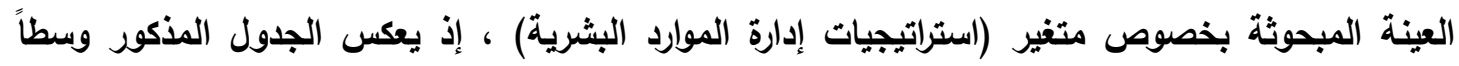

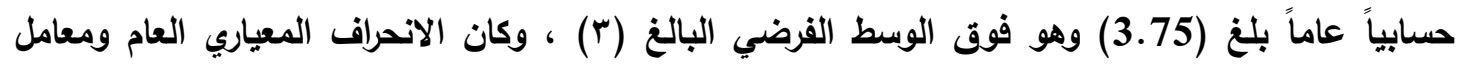
الاختلاف حولهما (0.56) (34.9\%) (14)، وفيما يأتي تثخيص لوقاقع المتغيرات الفرعية : أ. استراتيجة|لاختيار والتعيين (Z1) : حقق هذا البعد وسطا حسابيا عاما بلغ (3.75) وهو اعلى من الوسط الفرضي البالغ (3) ، وكان الانسجام ذو تثتت عالي في الإجابة يؤكده الانحراف المعياري ومعامل الاختلاف العامين اذ بلغا (0.56) ، 
14.9\%) على التوالي ـ أما على صعيد الفقرات فقد قيس هذا المتفير من خلال( 5) فقرات، وتراوحت النتائج

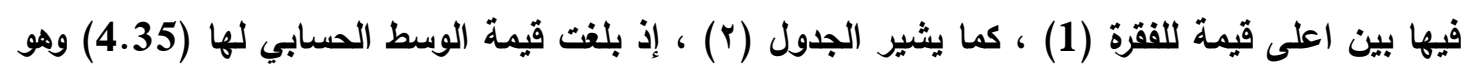

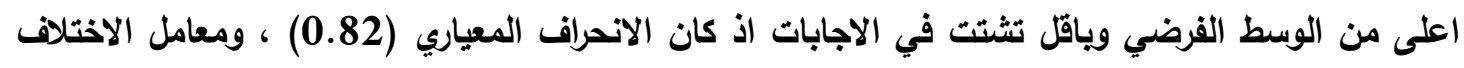

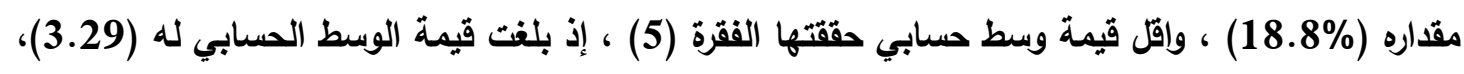
وهي اقل من الوسط الفرضي ويتشتت عالي في الإجابات، يعكسه الانحراف المعياري ومعامل الاختلاف البالغين (1.30) (39.6\%) (

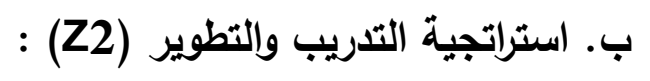

حقى هذا البعد وسطاً حسابياً عاما حول الوسط الفرضي ، إذ بلغ (3.71) ، ويتثتت عالي في الإجابة

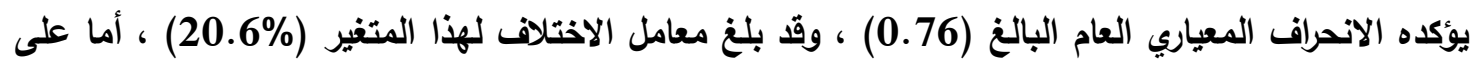

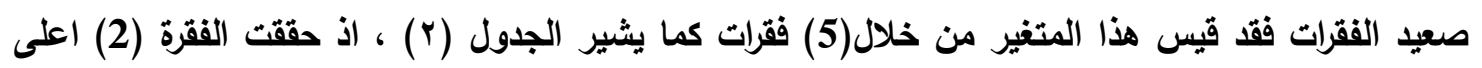
وسط الحسابي بلغ (3.84) وهي أعلى من قيمة الوسط الفرضي ، ويتشتت عالي بين الإجابات يؤكده الانحراف المعياري (1.00) ومعامل الاختلاف (26\%) وتثيطير هذه النتائج على ان صاحب المشروع يهتم بتدريب العاملين داخل وخارج المشروعات عندما تدعو الحاجة لذلك وهذا ما اكد عليه افراد العينة المبحوثة . وحققت الفقرة (1) و(4) على التوالي ، أدنى مستوى إجابة، إذ بلغت قيمة الوسط الحسابي لهما متساوياً

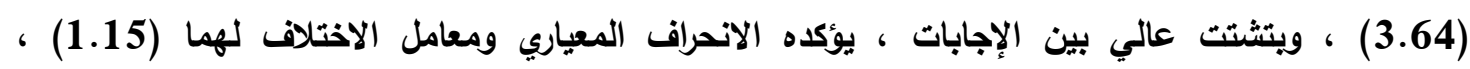

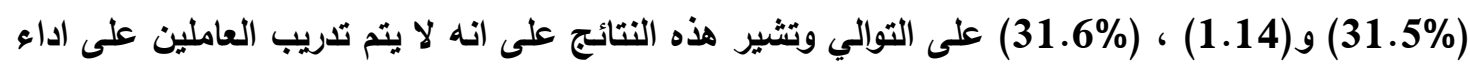
اكثر من وظيفة ولكن يتم التركيز على مهمة واحده فقط ، بالاضافة الى ان صاحب المشروع لا يعير اهتمام

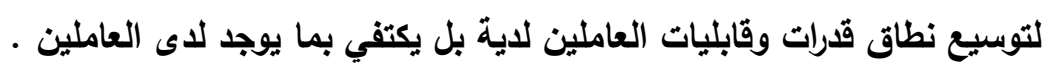
ج. استراتيجية الاجور والتعويضات (Z3) : يثير الجدول (r) إلى الأوساط الحسابية والانحرافات المعيارية معامل الاختلاف المتعلقة بوجهة نظر العينة

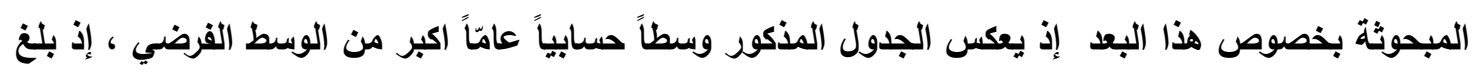

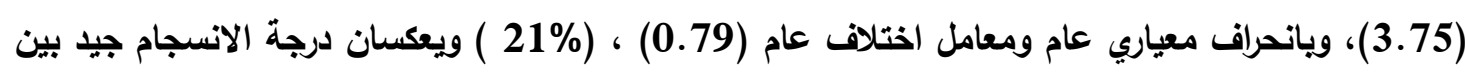

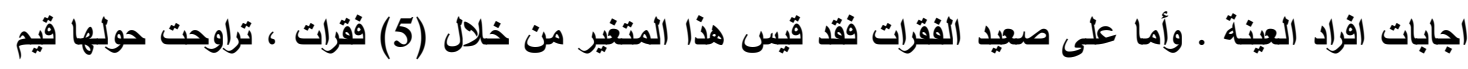

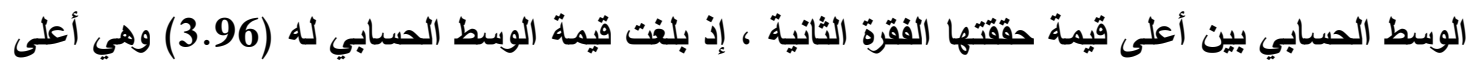

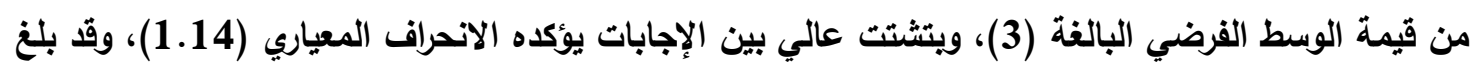

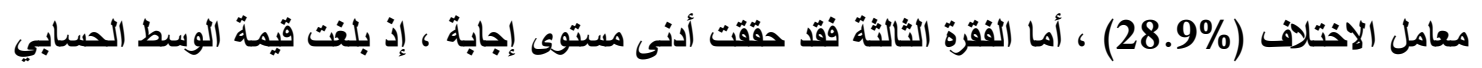
له (3.31) ، ويتشتت عالي بين الإجابات ، يؤكده الانحراف المعياري (1.36) وقد بلغ معامل الاختلاف 


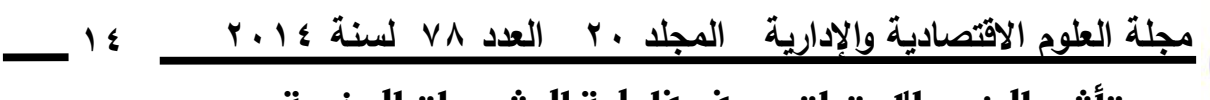

تأثير المنهج 1استتراتيجيي في فاعلية المشرو عات الصغيرة

$$
\text { والمتوسطة في العراق - بـهث ميدانيي }
$$

$$
\text { ع. استراتيجية تقييم الاداء (Z4) : }
$$

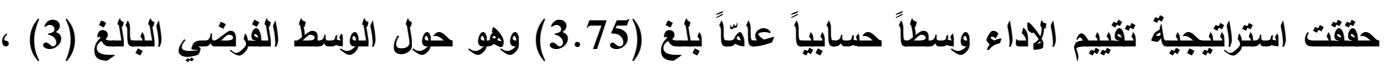

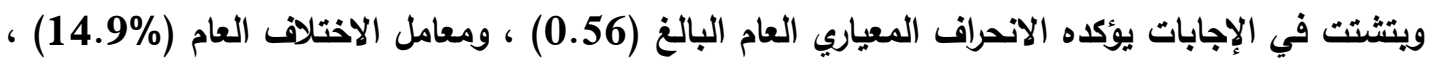

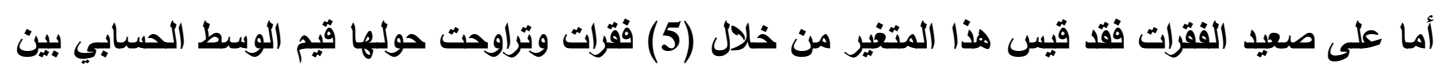

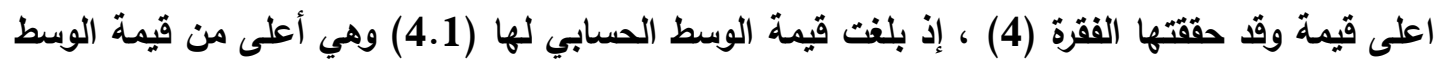

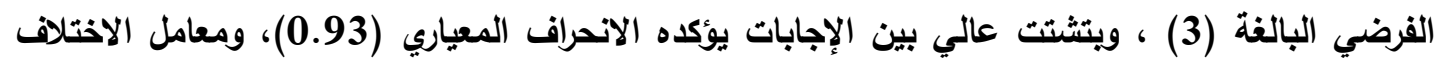

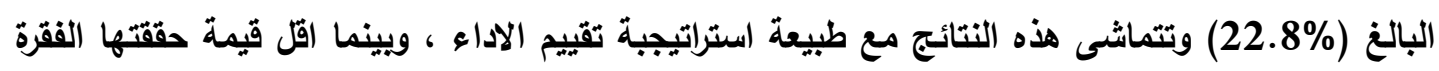

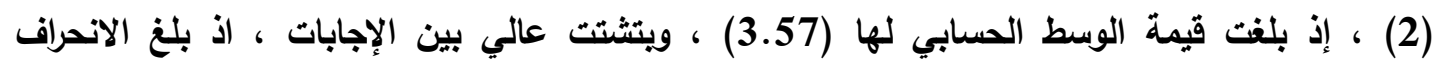

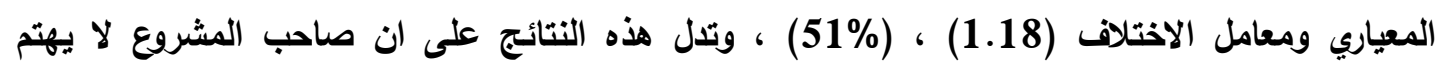
بمجالات تطوير العاملين لذاماتهم للاستفادة منها في تحسين الاداء الوظيفي . 


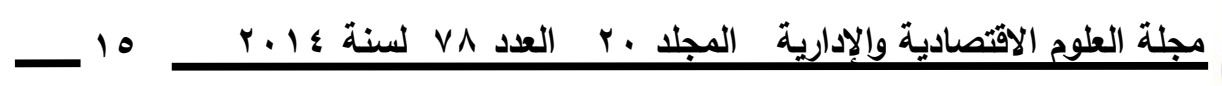

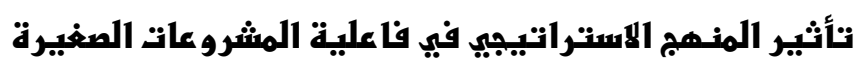

والمتوسطة في العراق - بـهث ميدانيي كئري

جدول (ץ) الوسط الحسابي والانحراف المعياري ومعامل الاختلاف للاستراتيجيات ادارة الموارد البشرية

\begin{tabular}{|c|c|c|c|c|c|}
\hline 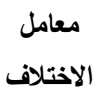 & 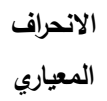 & الوسط الوبط & 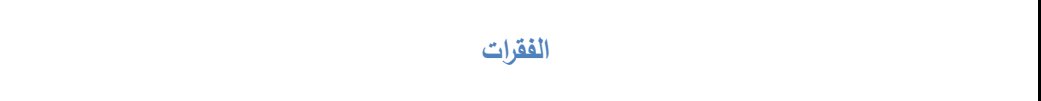 & \multicolumn{2}{|c|}{ 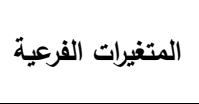 } \\
\hline 18.87 & 0.82 & 4.35 & منطلبات البيئة العراقية ـ العاملين ذوي المهارات المتنوعة للتعامل مـع الاعمال المتغيرة ، والاستعداد الجدي مـع & 1 & \multirow{6}{*}{ 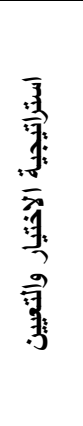 } \\
\hline 39.85 & 1.42 & 3.57 & يتخذ قرار تعيين العاملين الجدد بعيدآ عن المحاباة والوساطة والتحيز . & 2 & \\
\hline 28.16 & 1.06 & 3.77 & يخضع العاملون عند تعينهم في المشروع الى اختبارات مهنية ومقابلات توظيف فاعلة . & 3 & \\
\hline 26.15 & 0.99 & 3.82 & تعنمد كل التعيينات في المشروع على ميزة المتقدم (حيث يتم اختيار الثخص المناسب بغض النظر & 4 & \\
\hline 39.66 & 1.30 & 3.29 & لا يحتاج ولا يتطلب من المشروع الاهتمام بالطريقة التي يتم بها تعيين العاملين . & 5 & \\
\hline 19.58 & 0.73 & 3.76 & الوسط والانحراف ومعامل الاختلاف العام & & \\
\hline 31.59 & 1.15 & 3.64 & يتم تدريب العاملين على اداء وظائف متعددة داخل المشروع اكثر من التركيز على مهمة واحدة . & 6 & \multirow{6}{*}{ 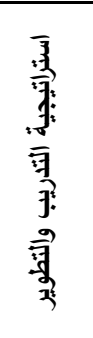 } \\
\hline 26.09 & 1.00 & 3.84 & يهتم المشروع بتدريب العاملين اثناء العمل ، وخارجه على حد سواء اذا دعت الحاجة. & 7 & \\
\hline 28.08 & 1.07 & 3.81 & يمتلك المشروع خطة قصيرة وبعيدة الأمد للتدريب تثمل كل العاملين فيه من اداريين وفنيين . & 8 & \\
\hline 27.19 & 0.99 & 3.64 & يشجع صاحب المشروع على توسيع نطاق قدات العاملين . & 9 & \\
\hline 31.60 & 1.14 & 3.62 & تتاح الفرص لمناقثة الاحتياجات التدريبية للعاملين مع صاحب المشروع. & 10 & \\
\hline 20.65 & 0.76 & 3.71 & الوسط والانحراف ومعامل الاختلاف العام & & \\
\hline 32.83 & 1.22 & 3.74 & يعمل المشروع بأسلوب دفع اجور مرنة متغيرة تحسب اداء العاملين للمهمة المناطة بهر . & 11 & \multirow{6}{*}{ 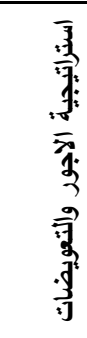 } \\
\hline 28.91 & 1.14 & 3.96 & تدفع الاجور للعاملين على اساس قيمة الوظيفة ، مع دفع مكافأت للمهارات الاضافية التي يمتلكونها . & 12 & \\
\hline 41.32 & 1.36 & 3.31 & يشترك العاملون والادارة معآ في تحديد الأجور والحوافز التي تدفع اليهم . & 13 & \\
\hline 25.60 & 0.99 & 3.87 & يلتزم المشروع بنظام دفع الأجور على وفق الأمتياز . & 14 & \\
\hline 28.18 & 1.10 & 3.91 & يعد دفع الحوافز ، مثل المكافأة بمثابة جزء مهم من استراتيجية التعويض في المشروع & 15 & \\
\hline 21.06 & 0.79 & 3.75 & الوسط والانحراف ومعامل الاختلاف العام & & \\
\hline 27.56 & 1.02 & 3.7 & يتبنى المشروع المداخل المتطورة في قياس الاداء الوظيفي للعاملين & 22 & \multirow{7}{*}{ 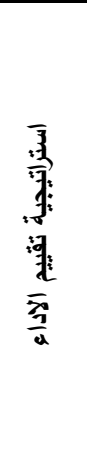 } \\
\hline 32.40 & 1.15 & 3.57 & لا اهتم كمالك للمشروع بمجالات تطوير الخدمات للموظفين للأستفادة منها في تحسين الاداء الوظيفي. & 23 & \\
\hline 25.77 & 0.97 & 3.79 & يعتمد المشروع آليات رسمية وغير رسمية معآ لمشاركة العاملين في ممارسات الاداء العالي ، واجراء & 24 & \\
\hline 22.85 & 0.93 & 4.1 & يعتمد المشروع في تقييم الاداء على النتائج القابلة للقياس الكمي · & 25 & \\
\hline 24.81 & 0.92 & 3.74 & يوفر المشروع معلومات كافية ، فيما يتعلق بأساليب محددة من نظام تقييم الاداء . & 26 & \\
\hline 16.99 & 0.64 & 3.78 & الوسط والانحراف ومعامل الاختلاف العام & 27 & \\
\hline 14.95 & 0.56 & 3.75 & اجمالي الوسط والانحراف ومعامل الاختلاف العام & & \\
\hline
\end{tabular}

r. فاعلية المشروعات الصغيرة والمتوسطة : قيس هذا المتغير من خلال اريعة متغيرات فرعية

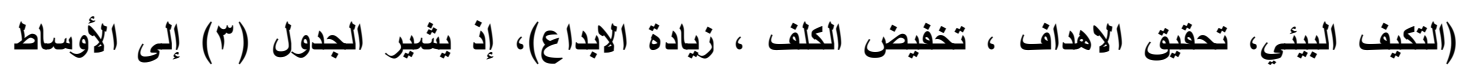

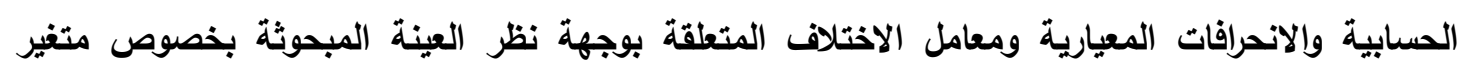

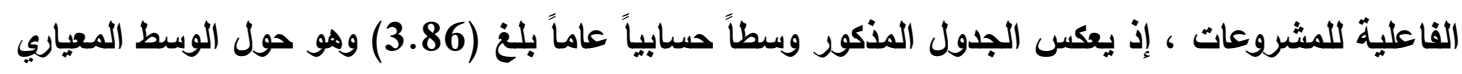

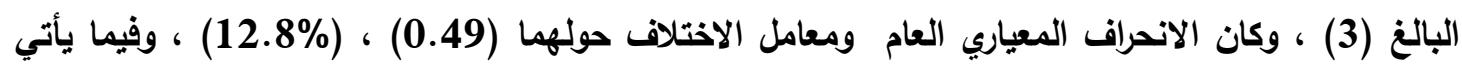




$$
\text { أ. التكيف البيئي (Y1) : (ب) }
$$

حقق هذا البعد وسطا حسابيا عاما بلغ (3.88) وهو اعلى من الوسط الفرضي البالغ (3) ، وكان

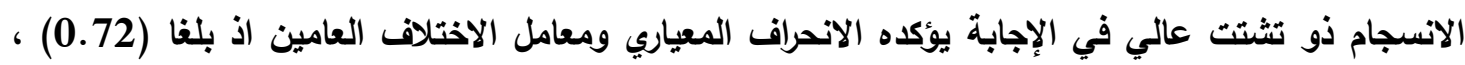

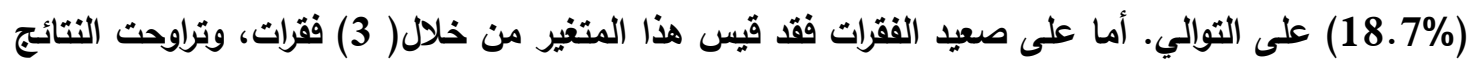

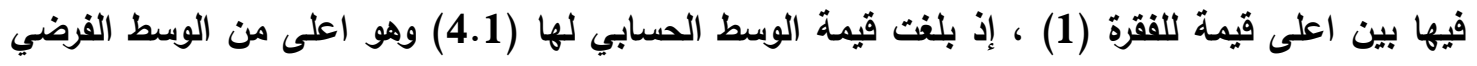

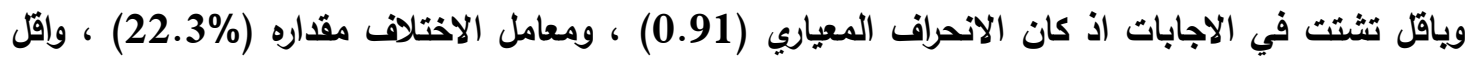

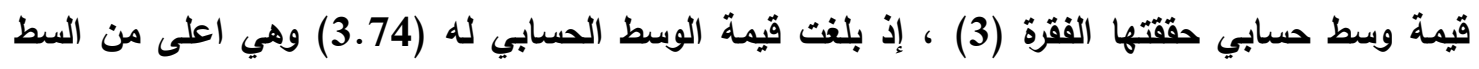

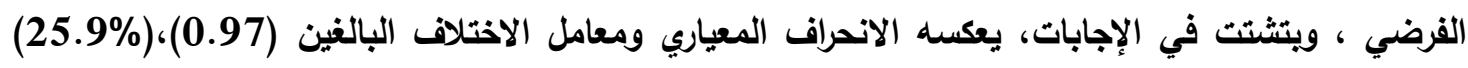

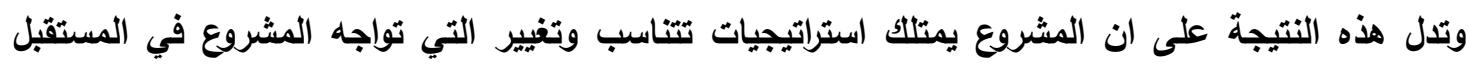

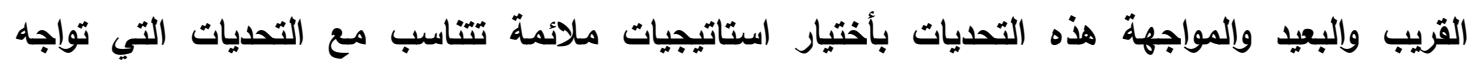

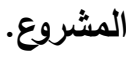

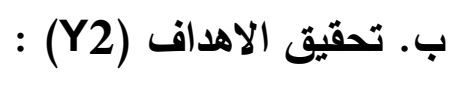

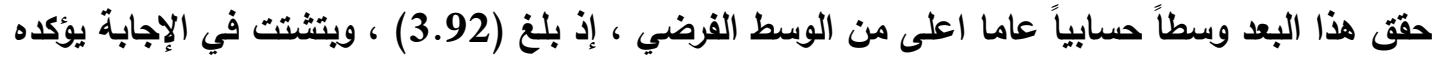

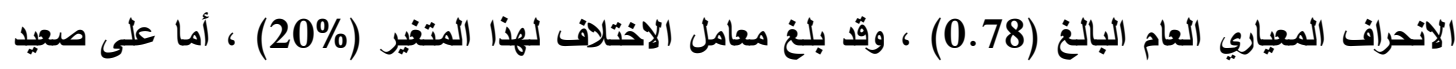

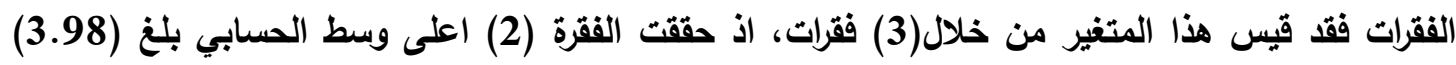

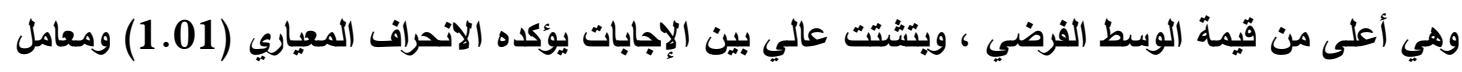

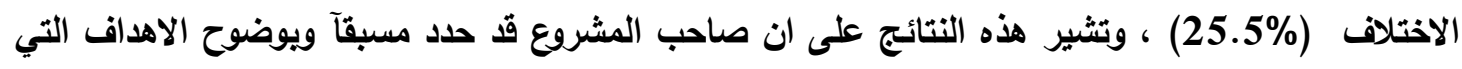

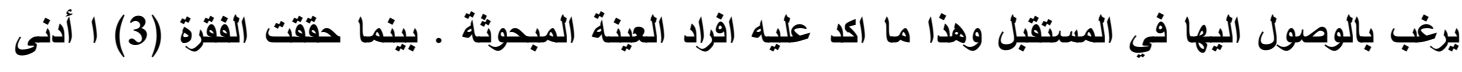

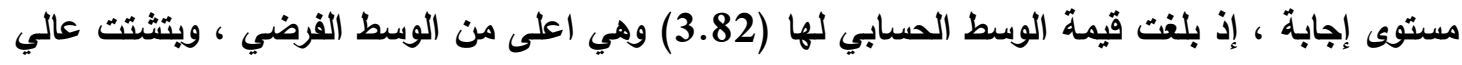

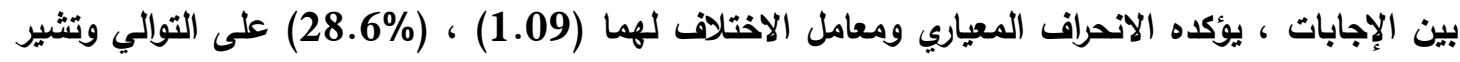

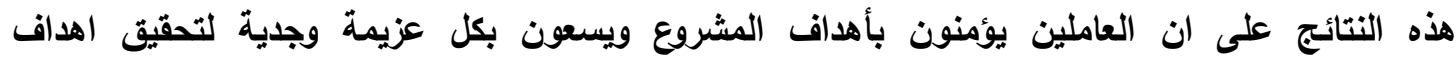

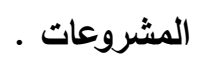

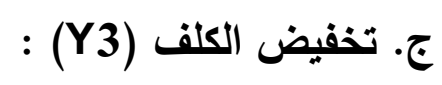

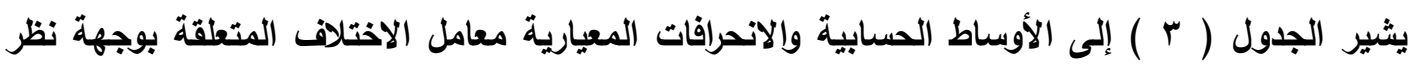

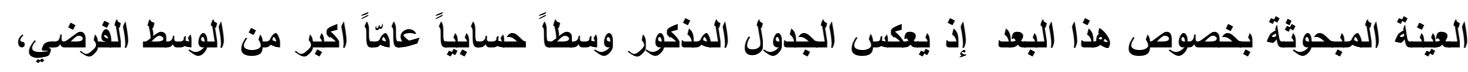

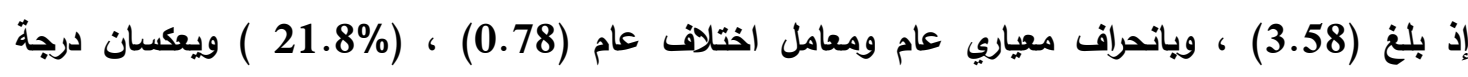

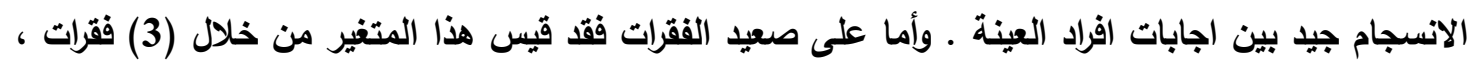

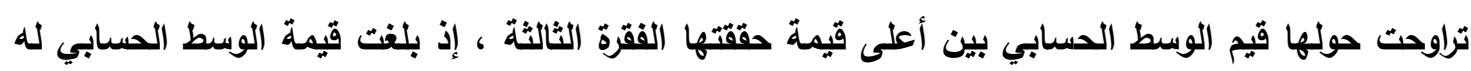

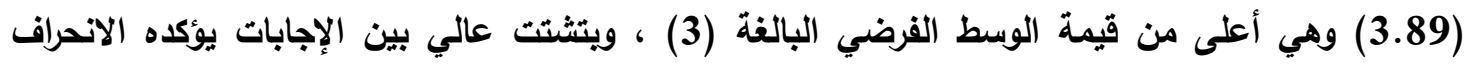

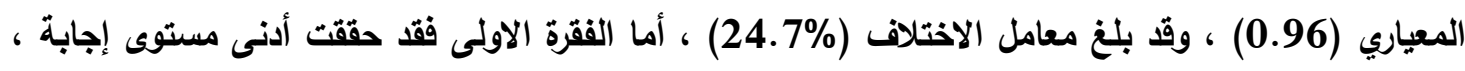

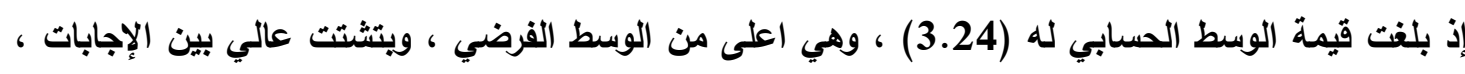

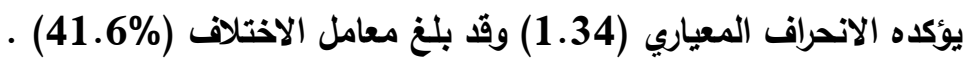




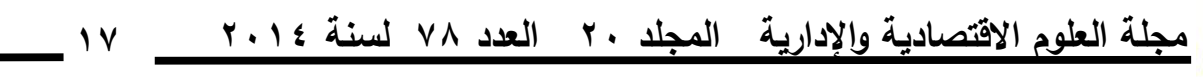

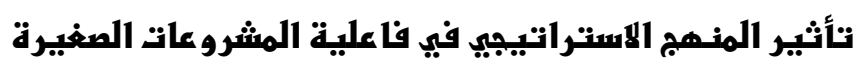

والمتوسطة في العراق - بـهث ميدانيي

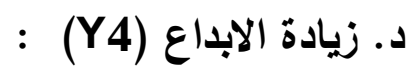

حققت زيادة الابداع وسطاً حسابياً عامّاً بلغ (3.86) وهو حول الوسط الفرضي البالغ (3) ، ويتثتت في

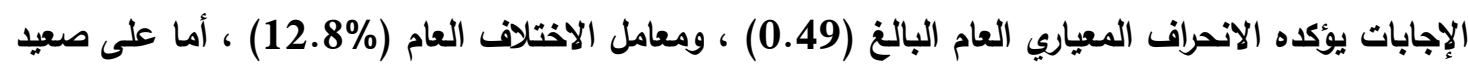

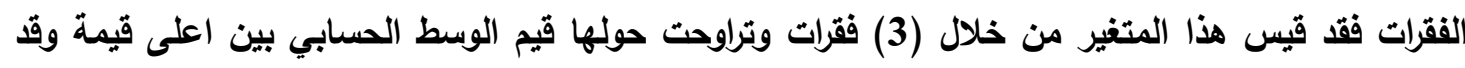

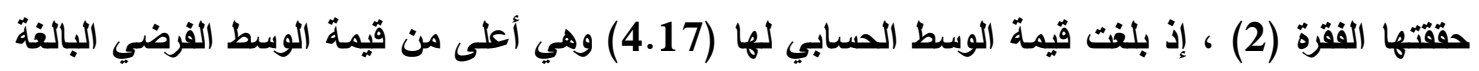
(3)، ويتثتت عالي بين الإجابات يؤكده الانحراف المعياري (0.76) ، ومعامل الاختلاف البالغ (18.3\%)

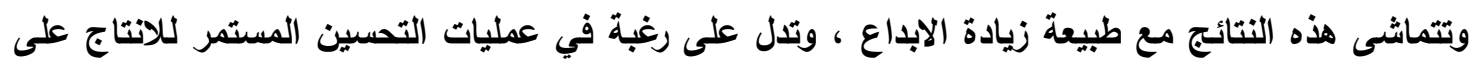

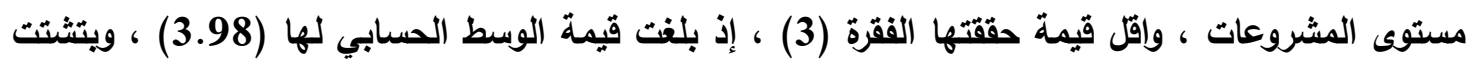
عالي بين الإجابات ، اذ بلغ الانحراف المعياري ومعامل الاختلاف (37) ،

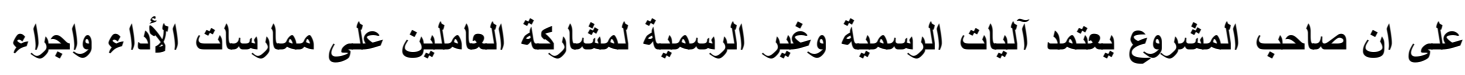

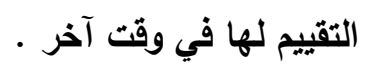

N=100 جدول (r) الوسط الحسابي والانحراف المعياري ومعامل الاختلاف للاستراتيجيات الاعمال

\begin{tabular}{|c|c|c|c|c|c|}
\hline 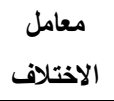 & 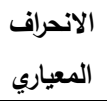 & الوسط الوسب & 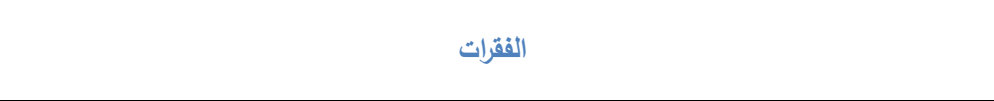 & \multicolumn{2}{|c|}{ المتغيرات الفرعية } \\
\hline 22.34 & 0.91 & 4.1 & يتكيف مشروعي مع طلبات الزيائن سعيآ منه لتقديم الافضل على الدوام & 1 & \multirow{4}{*}{$\begin{array}{l}\overline{\text { 可 }} \\
\overline{\text { 裂 }}\end{array}$} \\
\hline 25.36 & 0.96 & 3.8 & اعتقد ان مشروعي قادرآ على التعامل مع تحديات البيئة بشكل كبير . & 2 & \\
\hline 25.93 & 0.97 & 3.74 & يمتلك المشروع استراتيجيات تغيير نتناسب مع التحديات المتوقعة في المستقبل القريب والبعيد . & 3 & \\
\hline 18.73 & 0.72 & 3.88 & الوسط والانحراف ومعامل الاختلاف العام & & \\
\hline 24.31 & 0.96 & 3.96 & يوجد اتفاق مبائي بين الادارة والعاملين حول اهداف المشروع المطلوب تحقيقها . & 4 & \multirow{4}{*}{ 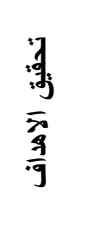 } \\
\hline 25.50 & 1.01 & 3.98 & تعد اهداف المشروع محددة بوضوح من حيث ما يتم الوصول اليه في المستقبل . & 5 & \\
\hline 28.66 & 1.09 & 3.82 & يؤمن العاملون بأهداف المشروع ، ويسعون لتحقيقها بكل جدية . & 6 & \\
\hline 20.08 & 0.78 & 3.92 & الوسط والانحراف ومعامل الاختلاف العام & & \\
\hline 41.63 & 1.34 & 3.24 & لاو يهنجي كصاحب مشروع توسيع قوة العمل بحكم قياس ذلك بالانتاجية المقدمة على شكل خدمات & 7 & \multirow{4}{*}{$\begin{array}{l}\text { 括 } \\
\text { 可 } \\
\text { 可 }\end{array}$} \\
\hline 24.95 & 0.90 & 3.63 & تعد حالات الهدر والضياعات بالموارد على مستوى المشروع ضئيلة جدآ قياسآ بمشروعات اخرى . & 8 & \\
\hline 24.75 & 0.96 & 3.89 & يعتبر حجم مخرجات انتاج المشروع متناسبآ مع قياسات كلفة المدخلات من الموارد . & 9 & \\
\hline 21.87 & 0.78 & 3.58 & الوسط والانحراف ومعامل الاختلاف العام & & \\
\hline 18.33 & 0.74 & 4.08 & لا يهمني التركيز على مجالات تطوير السوق ، بل اكتفي بما اقدمه للزبائن في الوقت الحاضر. & 10 & \multirow{5}{*}{ 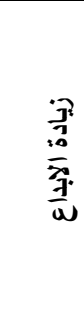 } \\
\hline 18.36 & 0.76 & 4.17 & لا اهتم كمالك للمشروع بمجالات تطوير الخدمات او المنتجات المقدمة للزيائن . & 11 & \\
\hline 19.54 & 0.77 & 3.98 & استجيب لعوامل البيئة الخارجية فقط ، عندما تصبح مؤئرة في كفاءة مشروعي. & 12 & \\
\hline 15.71 & 0.64 & 4.07 & الوسط والانحراف ومعامل الاختلاف العام & & \\
\hline 12.81 & 0.49 & 3.86 & اجمالي الوسط والانحراف ومعامل الاختلاف العام & & \\
\hline
\end{tabular}




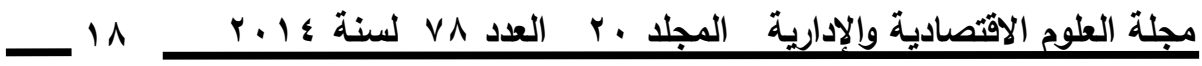

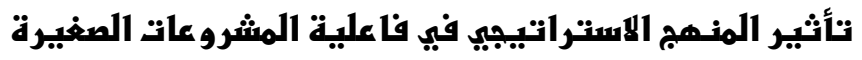

والمتوسطة في العراق - بـهث ميدانيي

ثانيا : اختبار الفرضيات

1. تحليل علاقات الارتباط بين استراتيجيات الاعمال واستراتيجيات إدارة الموارد البشرية

نصت الفرضية الاساسية الاولى : توجد علاقة ايجابية ذات دلالة معنوية بين استراتيجيات الاعمال للمشروعات الصغيرة والمتوسطة واستراتيجيات إدارة الموارد البشرية التي تمارسها " وقث انبثقت منها اريعة فرضيات فرعية ، اذ يوضح الجدول ( ؛ ) مصفوفة علاقات الارتباط بين متغير استراتيجيات الاعمال وابعادها

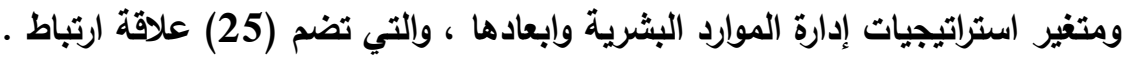

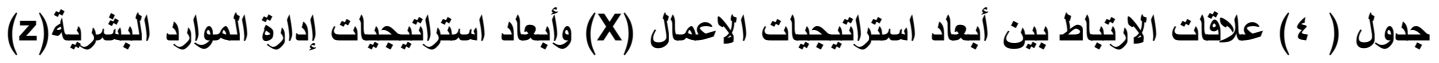
على مستوى المشروعات الصغيرة والمتوسطة

\begin{tabular}{|c|c|c|c|c|c|c|c|c|}
\hline \multicolumn{2}{|c|}{ العلاقات المعنوية } & \multirow{2}{*}{ استراتيجيات الاعمال } & \multirow{2}{*}{ الاستراتيجية } & \multirow{2}{*}{ الاستراتيجية } & \multirow{2}{*}{ الاستراتيجية } & \multirow{2}{*}{ الاستراتيجية } & \multirow{2}{*}{\multicolumn{2}{|c|}{ الموارد البشرية إنيجات إدارة }} \\
\hline الاهمية & 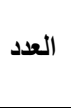 & & & & & & & \\
\hline$\% 100$ & 5 & $0.352^{* *}$ & $0.276^{* * *}$ & $0.201^{*}$ & $0.246^{*}$ & $0.359^{* *}$ & \multicolumn{2}{|c|}{ استراتيجية الاختيار والتعيين } \\
\hline$\% 80$ & 4 & $0.499^{* *}$ & $0.444^{* *}$ & 0.143 & $0.563^{* *}$ & $0.395^{* *}$ & \multicolumn{2}{|c|}{ استراتيجية التدريب والتطوير } \\
\hline$\% 100$ & 5 & $0.504^{* *}$ & $0.305^{* 6}$ & $0.375^{* *}$ & $0.482^{* *}$ & $0.364^{* *}$ & \multicolumn{2}{|c|}{ استراتيجية الاجور والتعويضات } \\
\hline- & - & 0.078 & -0.143 & 0.181 & 0.108 & 0.056 & \multicolumn{2}{|c|}{ استراتيجية تقييم الاداء } \\
\hline$\% 100$ & 5 & $0.563^{* *}$ & $0.350^{* *}$ & $0.352^{* *}$ & $0.543^{* *}$ & $0.468^{* *}$ & \multicolumn{2}{|c|}{ اجمالي استراتيجيات إدارة الموارد } \\
\hline & 19 & 4 & 4 & 3 & 4 & 4 & 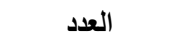 & \multirow{2}{*}{ العلاقات المعنوية } \\
\hline$\% 84$ & & $80 \%$ & $80 \%$ & $60 \%$ & $80 \%$ & $80 \%$ & الأهمية النسبية & \\
\hline
\end{tabular}

0,05 الارتباط ذات دلالة معنوية عند مستوى الابة

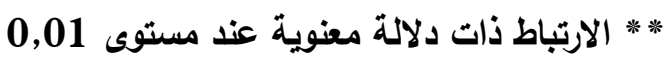

أ. تحليل علاقة الارتباط بين الاستراتيجية المدافعة (X1) واستراتيجيات إدارة الموارد البشرية وإبعادها : بلغت قيمة علاقات الارتباط بين الاستراتيجية المدافعة وبين أبعاد استراتيجيات إدارة الموارد البشرية كما

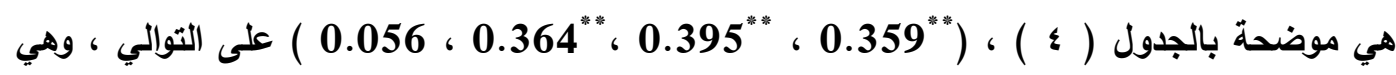
جميعها علاقات ارتباط موجبة وذات دلالة معنوية عند مستوى (0,01) ، باستثناء العلاقة بين الاستراتيجية المدافعة ويعد استراتيجية تقييم الاداء علاقة موجبة ولكن غير معنه منوية منابة من الناحية

الاحصائية.

ب. تحليل علاقة الارتباط بين الاستراتيجية المنقبة (X2) واستراتيجيات إدارة الموارد البشرية التي تمارسها : يوضح الجدول (ع ) علاقات الارتباط بين الاستراتيجية المنقبة وبين استراتيجيات إدارة الموارد البشرية الماتية

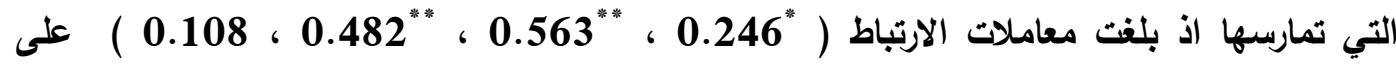
التوالي ، اذن جميع علاقات الارتباط هي علاقات موجبة وذات دلالة معنوية عند مستوى (0,01) و(0,05) ، باستثناء العلاقة بين بعد الاستراتيجية المنقبة ويعد استراتيجية تقييم الاداء ، اذ كانت العلاقة بينهما موجبة ولكن غير معنوية وهي اضعف العلاقات من الناحية الاحصائية . 
ت. تحليل علاقة الارتباط بين الاستراتيجية المحلة (X3) واستراتيجيات إدارة الموارد البشرية التي تمارسها :

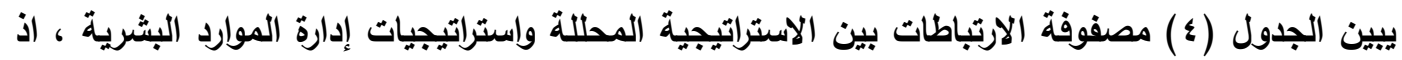

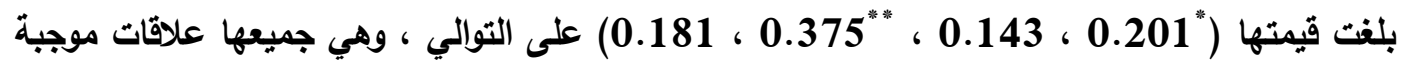
وذات دلالة معنوية عند مستوى (0,01) و(0,05) ، في حين كانت أقوى علاقة بين بعد " الاستراتيجية المحلة " ويعد " استراتيجية الاجور والتعويضات "، وهذه النتيجة تثير ويدلالة واضحة الى اهتمام العينة المبحوثة بتعزيز الاستراتيجية المحلة لاى مواردها البشرية من خلال برامج المكآفئات للأجور

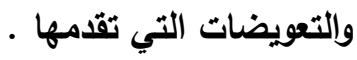
ث. تحليل علاقة الارتباط بين الاستراتيجية المستجيبة (X4) واستراتيجيات إدارة الموارد البشرية التي

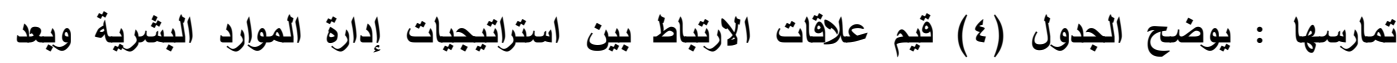

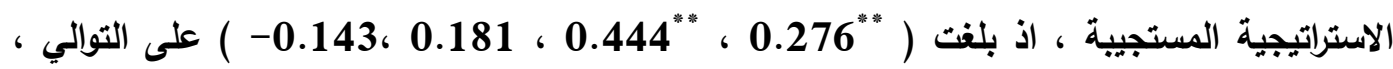
وهي جميعها علاقات موجبة ، بأستثناء بعد استراتيجية تقييم الأداء حيث كانت علاقة سالبة ، وكانت علاقة الاستراتيجية المستجيبة ويعد الاجور والتعويضات علاقة موجبة ولكن غير معنوية من الناحية

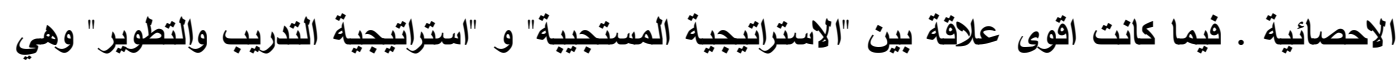

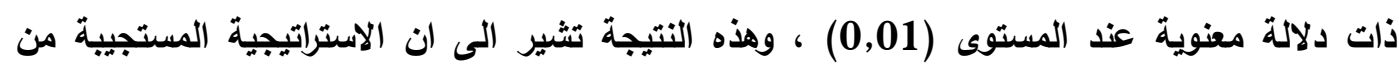

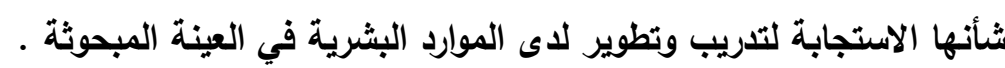
r. تحليل أثر استراتيجيات الاعمال في فاعلية المشروعات : يوضح الجدول ( • ) نتائج تحليل أثر استراتيجيات الاعمال (المتغير التفسيري) من خلال أبعادها الأربعة في فاعلية المشروعات (المتغير الاستجابي) وذلك باستخدام معامل الانحدار المتعدد ، وتم الاعتماد على قيمة

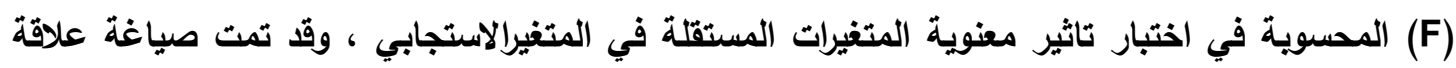
دالية بينهما كما في الجدول الأتي : جدول ( ه ) تاثير استراتيجيات الاعمال وابعادها في فاعلية المشروعات

\begin{tabular}{|c|c|c|c|c|c|c|}
\hline \multicolumn{7}{|c|}{ فاعلية المشروعات (Y) } \\
\hline المعنوية & $\mathbf{F}$ & $\mathbf{R}^{2}$ & المعنوية & $\mathbf{t}$ & B & X اسراتيجيات الاعمال \\
\hline \multirow{4}{*}{0.001} & \multirow{4}{*}{7.024} & \multirow{4}{*}{0.23} & 0.305 & 1.030 & 0.050 & الاستراتيجية المدافعة X1 \\
\hline & & & 0.005 & 2.877 & 0.178 & الاستراتيجية المنقبة X2 \\
\hline & & & 0.046 & 2.023 & 0.145 & الاستراتيجية المحلة X3 \\
\hline & & & 0.277 & $\begin{array}{c}- \\
1.094\end{array}$ & $\begin{array}{c}- \\
0.059\end{array}$ & الاستراتيجية المستجيبة X4 \\
\hline
\end{tabular}

0,05 الارتباط ذات دلالة معنوية عند مستوى 0.

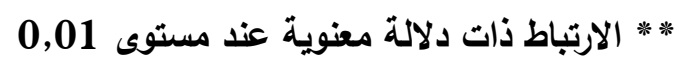




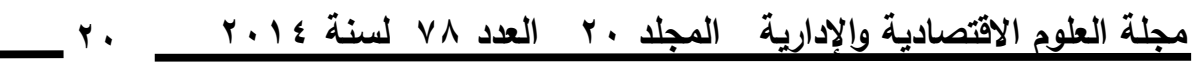

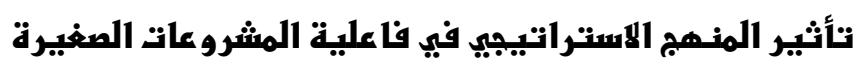
والمتوسطة في العراق - بـهث ميداني

وفيما يلي استعراض نتائج تحليل تأثير استراتيجيات الاعمال وابعادها في فاعلية المشروعات وكالأتي :

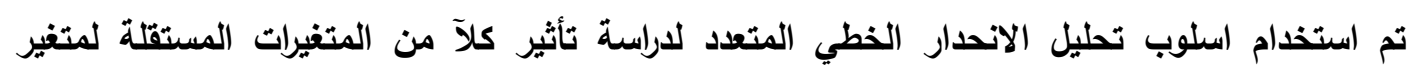

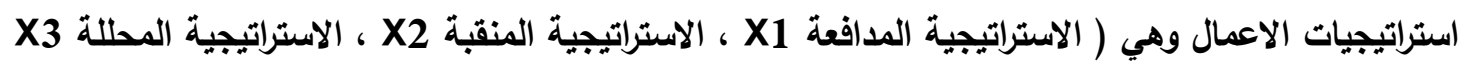
الاستراتيجية المستجيبة X4) على المتغير التابع فاعلية المشروعات (Y) كما ظهر في الجدول (

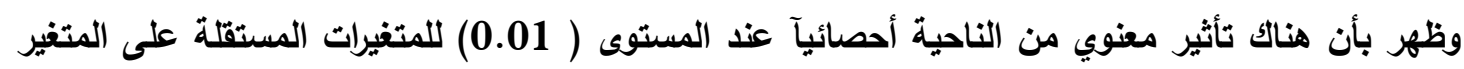

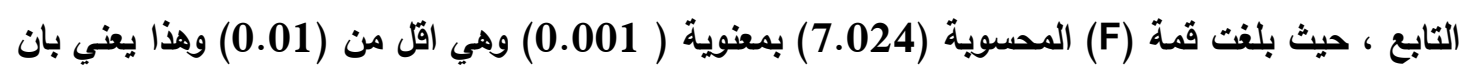
هناك تاثير معنوي احصائياً لمتغيرات استراتيجيات الاعمال على فاعلية المشروعات ، علمآ بأن قوة التأثنير

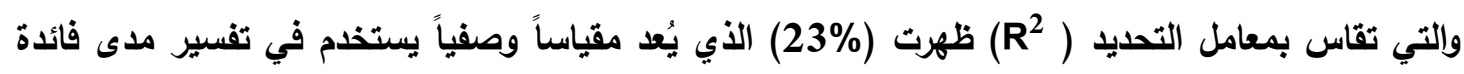

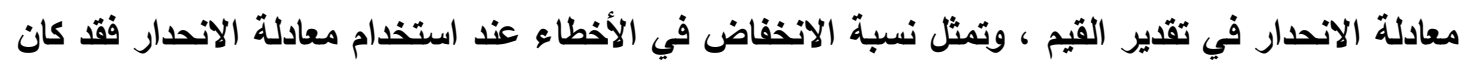

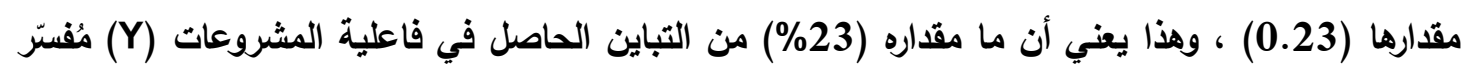

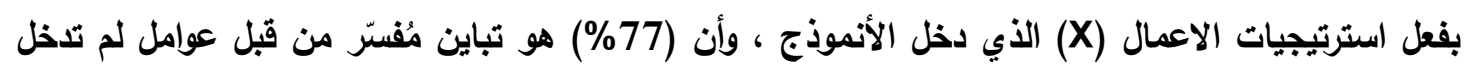

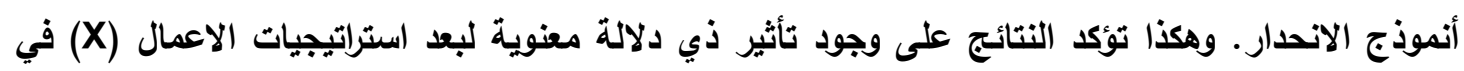

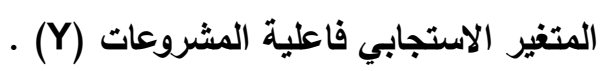
إما المتغيرات المستقلة الاكثر تأثيرآ على فاعلية المشروعات (Y) هي ( الاستراتيجية المنقبة) حيث بلغت

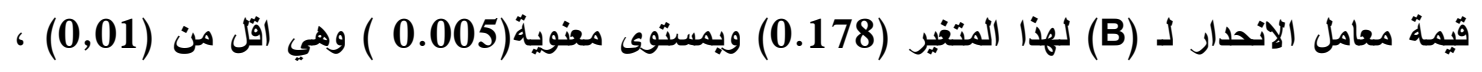

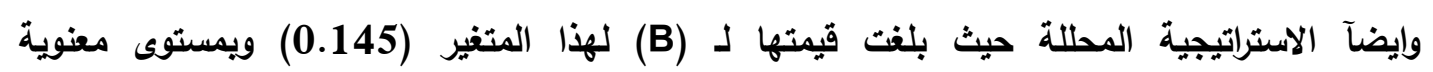
(0.046)وهي اقل من (0.05) وهذة النتيجة تثبير ويدلالة واضحة الى وجود تأثير بين استراتيجيات الاعمال

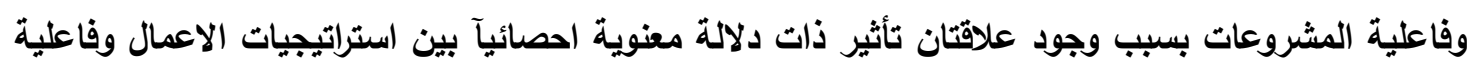

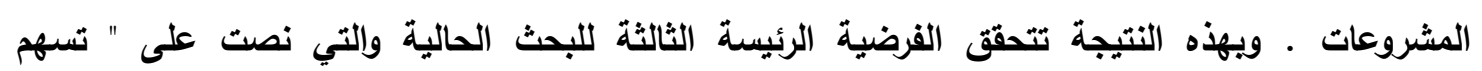

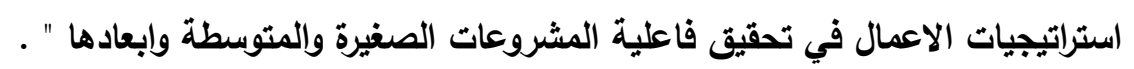

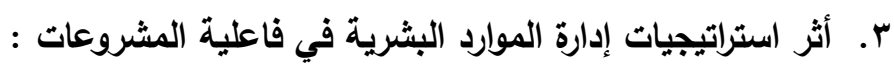

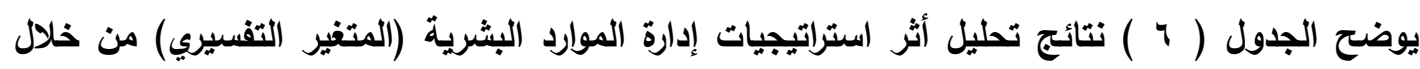

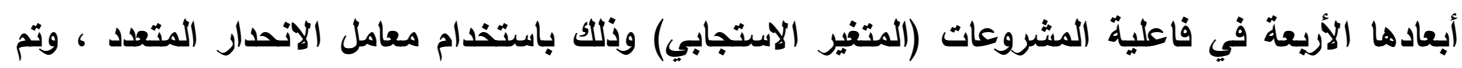

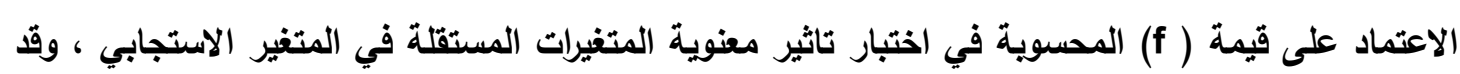
تمت صياغة علاقة دالية بينهما كما في الجدول الأتي :

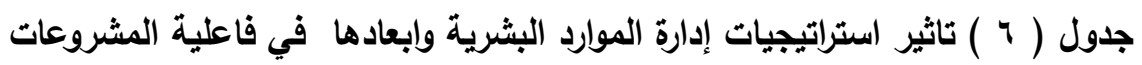

\begin{tabular}{|c|c|c|c|c|c|c|}
\hline \multicolumn{7}{|c|}{ فاعلية المشروعات (Y) } \\
\hline المعنوية & $\mathbf{F}$ & $\mathbf{R}^{2}$ & المعنوية & $\mathbf{t}$ & B & z اسراتيجيات إدارة الموارد البشرية \\
\hline \multirow{4}{*}{0.001} & \multirow{4}{*}{$\begin{array}{c}15.9 \\
8\end{array}$} & \multirow{4}{*}{0.40} & 0.093 & 1.697 & 0.115 & Z الاستراتيجية الاختيار والتعيين 1 \\
\hline & & & 0.343 & 0.953 & 0.065 & الاستراتيجية التدريب والتطوير Z2 \\
\hline & & & 0.001 & 3.497 & 0.200 & الاستراتيجية الأجور والتعويضات Z3 \\
\hline & & & 0.016 & 2.454 & 0.185 & Z4 الاستراتيجية تقييم الاداء \\
\hline
\end{tabular}


تم استخدام اسلوب تحليل الانحدار الخطي المتعدد لاراسة تأثير كلآ من المتغيرات المستقلة لمتغير

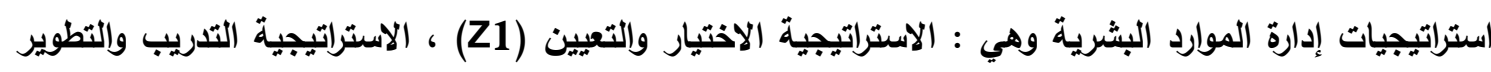

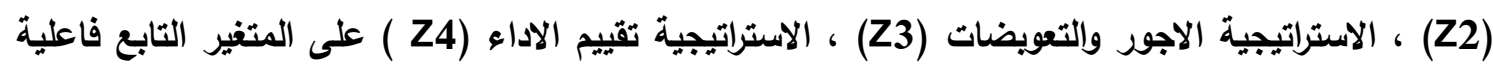

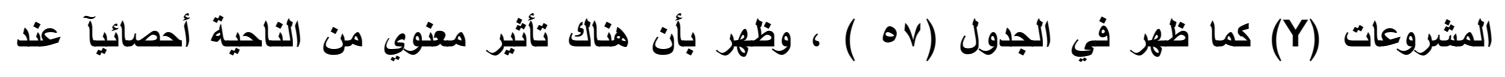

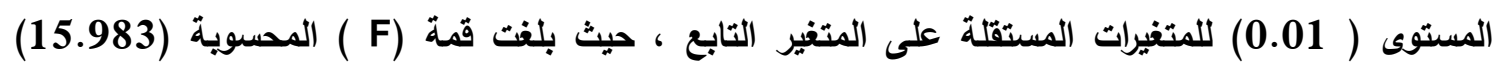

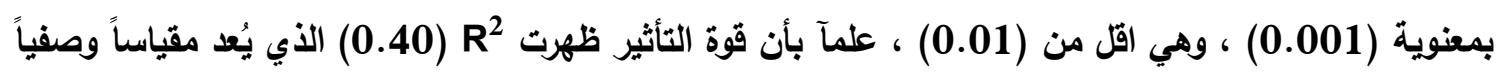

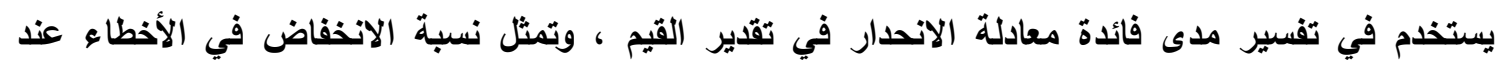

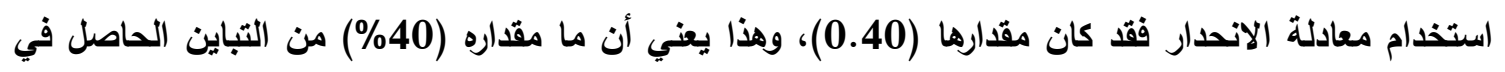

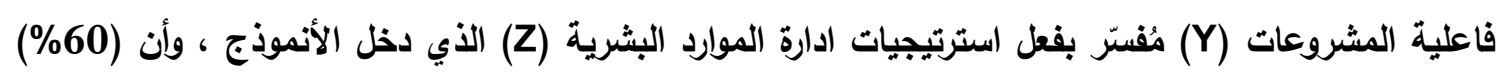

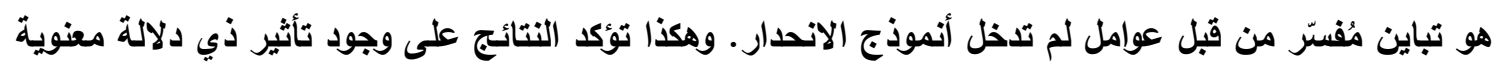

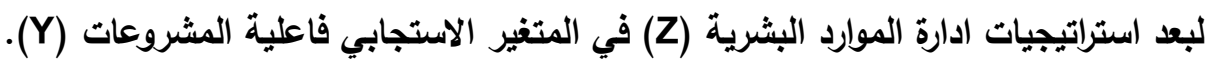

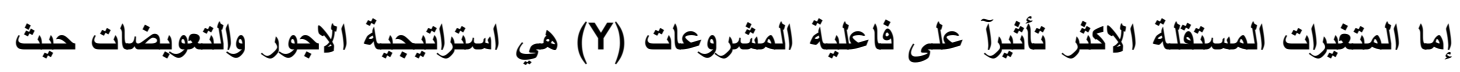

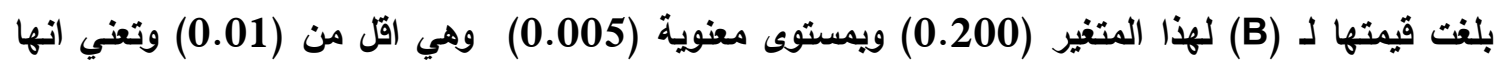

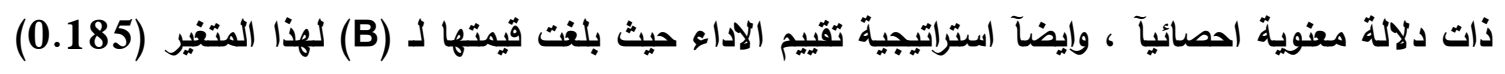
ويمستوى معنوية (0.016) وهي اقل من (0,05) وتعني انها ذات دلالة معنوية احصائياً ، وهذة النتيجة

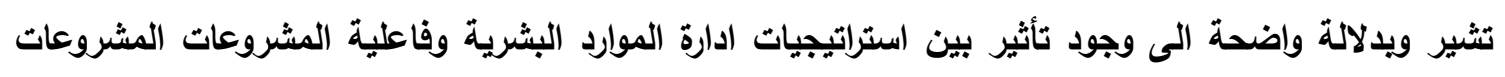

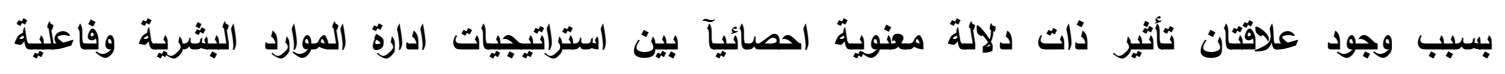

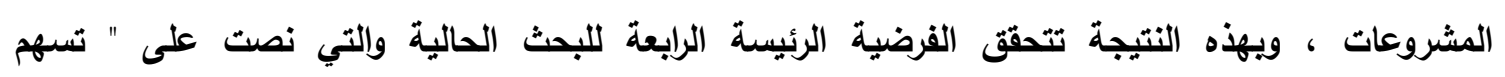

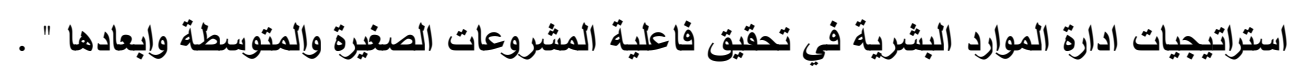

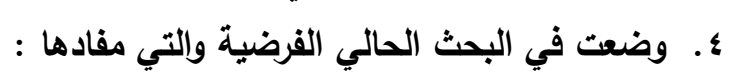

(تتأثر فاعليـة المشـروعات الصغيرة والمتوسطة باستراتيجيات الاعمـال أكثر من استراتيجيات إدارة المـوارد

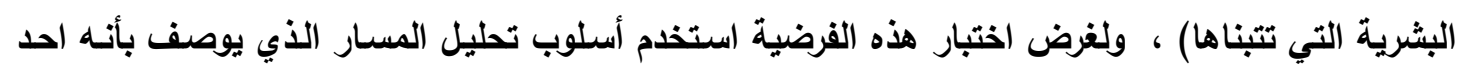

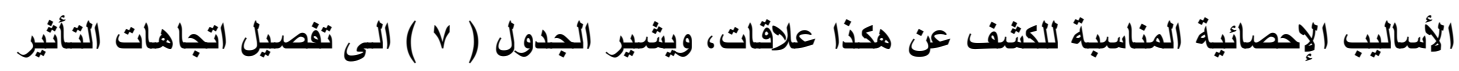




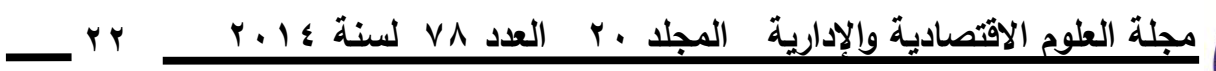

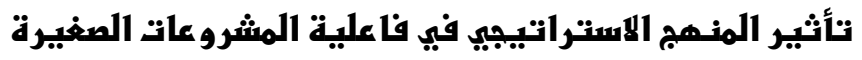

$$
\text { والمتوسطة في العراق - بـثث ميدانيي }
$$

جدول ( V ) تأثير استراتيجية الاعمال في فاعلية المشروعات الصغيرة والمتوسطة بتوسيط استراتيجيات إدارة الموارد البشرية

\begin{tabular}{|c|c|c|c|c|c|}
\hline \multicolumn{3}{|c|}{ r- تأثير الاستراتيجية المحلة في فاعلية المشروعات الصغيرة والمتوسطة } & \multicolumn{3}{|c|}{1 - تأثير اجمالي استراتيجيات الاعمال في فاعلية المشروعات الصغيرة } \\
\hline 0.2097 & \multicolumn{2}{|l|}{ تأثير مباشر } & 0.0599 & \multicolumn{2}{|l|}{ ت تأثير مباشر } \\
\hline 0.0548 & عن طريق استراتيجية الاختيار والتعيين & \multirow{6}{*}{ 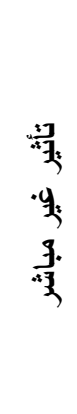 } & 0.0742 & عن طريق استراتيجية الاختيار والتعيين & \multirow{6}{*}{ 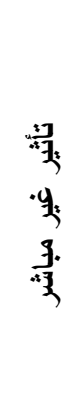 } \\
\hline 0.0061 & عن طريق استراتيحية التعويضات والاجور & & 0.0421 & عن طريق استراتيحية التعويضات والاجور & \\
\hline 0.0501 & عن طريق استراتيجية التدريب والتطوير & & 0.1100 & عن طريق استراتيجية التدريب والتطوير & \\
\hline 0.0883 & عن طريق استراتيجية تقييم الاداء & & 0.0829 & عن طريق الاستراتيجية تقييم الاداء & \\
\hline 0.1993 & مجموع التأثير غير المباشر & & 0.3092 & مجموع التأثير غير المباشر & \\
\hline 0.409 & التاشير الكلي & & 0.3691 & التأثير الكلي & \\
\hline \multicolumn{3}{|c|}{ ء - تأثير الاستراتيجية المدافعة في فاعلية المشروعات الصغيرة والمتوسطة } & \multicolumn{3}{|c|}{ - ت تأثثر الاستراتيجية المنقبة في فاعلية المشروعات الصغيرة والمتوسطة } \\
\hline 0.0947 & \multicolumn{2}{|l|}{ تأثير مباشر } & 0.0080 & \multicolumn{2}{|l|}{ ت تأثير مباشر } \\
\hline 0.0599 & عن طريق استراتيجية الاختيار والتعيين & \multirow{6}{*}{ 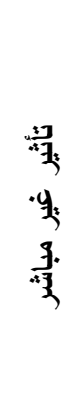 } & 0.0605 & عن طريق الاستراتيجية الاختيار والتعيين & \multirow{6}{*}{ 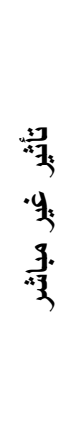 } \\
\hline 0.0317 & عن طريق استراتيحية التعويضات والاجور & & 0.0247 & عن طريق الاستراتيحية التعويضات والاجور & \\
\hline 0.1126 & عن طريق الاستراتيجية التدريب والتطوير & & 0.0643 & عن طريق استراتيجية التدريب والتطوير & \\
\hline 0.0726 & عن طريق استراتيجية تقييم الاداء & & 0.0654 & عن طريق استراتيجية تقييم الاداء & \\
\hline 0.2768 & مجموع التأثير غير المباشر & & 0.2149 & مجموع التأثير غير المباشر & \\
\hline 0.3715 & التأثير الكلي & & 0.2229 & التأثير الكلي & \\
\hline & & & \multicolumn{3}{|c|}{ ه- تأثير الاستراتيجية المستجيبة في فاعلية المشروعات الصغيرة } \\
\hline & & & -0.1130 & \multicolumn{2}{|l|}{ تأثير مباشر } \\
\hline & & & 0.0093 & عن طريق استراتيجية الاختيار والتعيين & \multirow{6}{*}{ 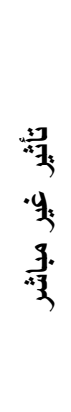 } \\
\hline & & & 0.0135 & عن طريق استراتيحية التعويضات والاجور & \\
\hline & & & 0.0624 & عن طريق استراتيجية التدريب والتطوير & \\
\hline & & & -0.0289 & عن طريق الاستراتيجية تقييم الاداء & \\
\hline & & & 0.0563 & مجموع التأثير غير المباشر & \\
\hline & & & -0.0567 & التأثير الكلي & \\
\hline
\end{tabular}


يبين الجدول ( 1 ) قيم التاثير المباشر وغير المباشر والكلي لستراتيجيات الاعمال في فاعلية المشروعات

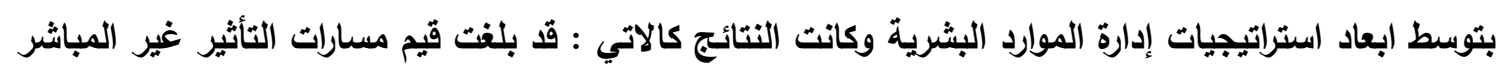

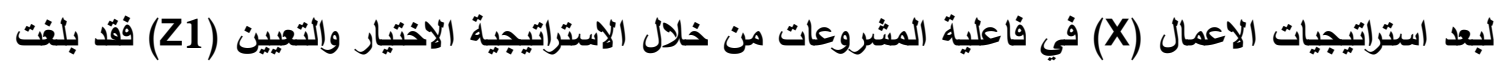

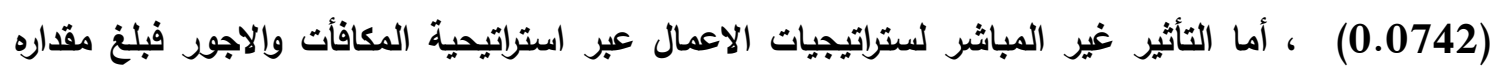
(0.0421) ، بينما كان التأثير غير المباثر عبر الاستراتيجية التدريب والتطوير (0.1100) ، (0.142) ، ويلغت قيمة

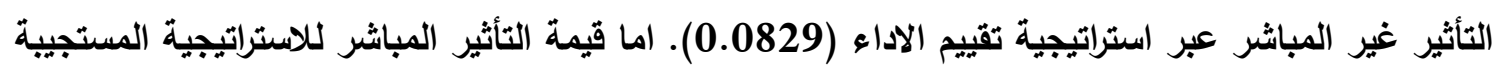

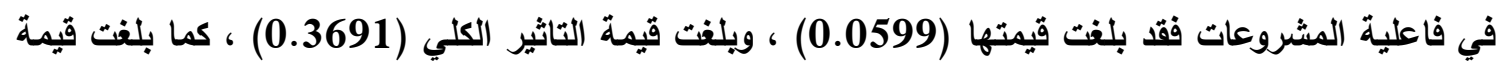

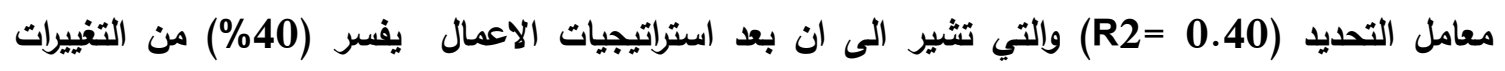

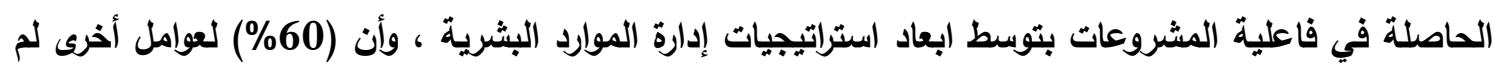

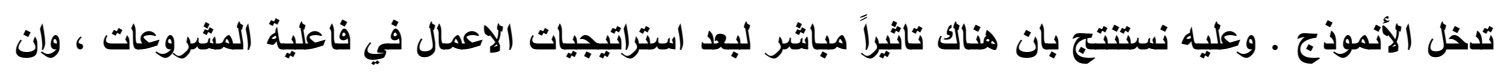

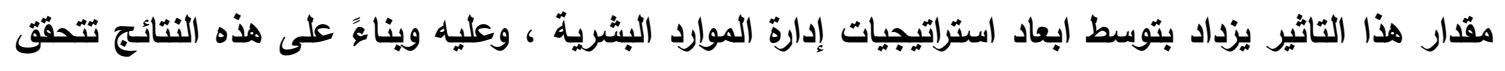

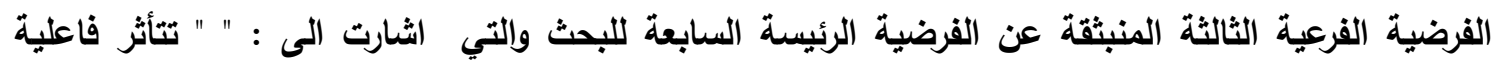

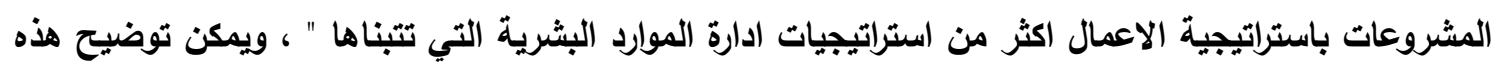
النتائج من خلال الثكل ( 1 ( ) : 


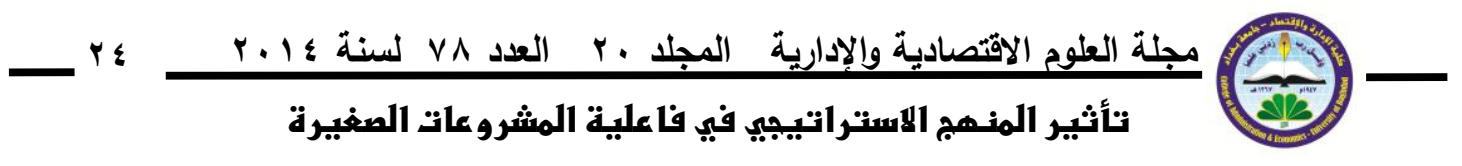
والمتوسطة في العراق - بـهث ميدانيي

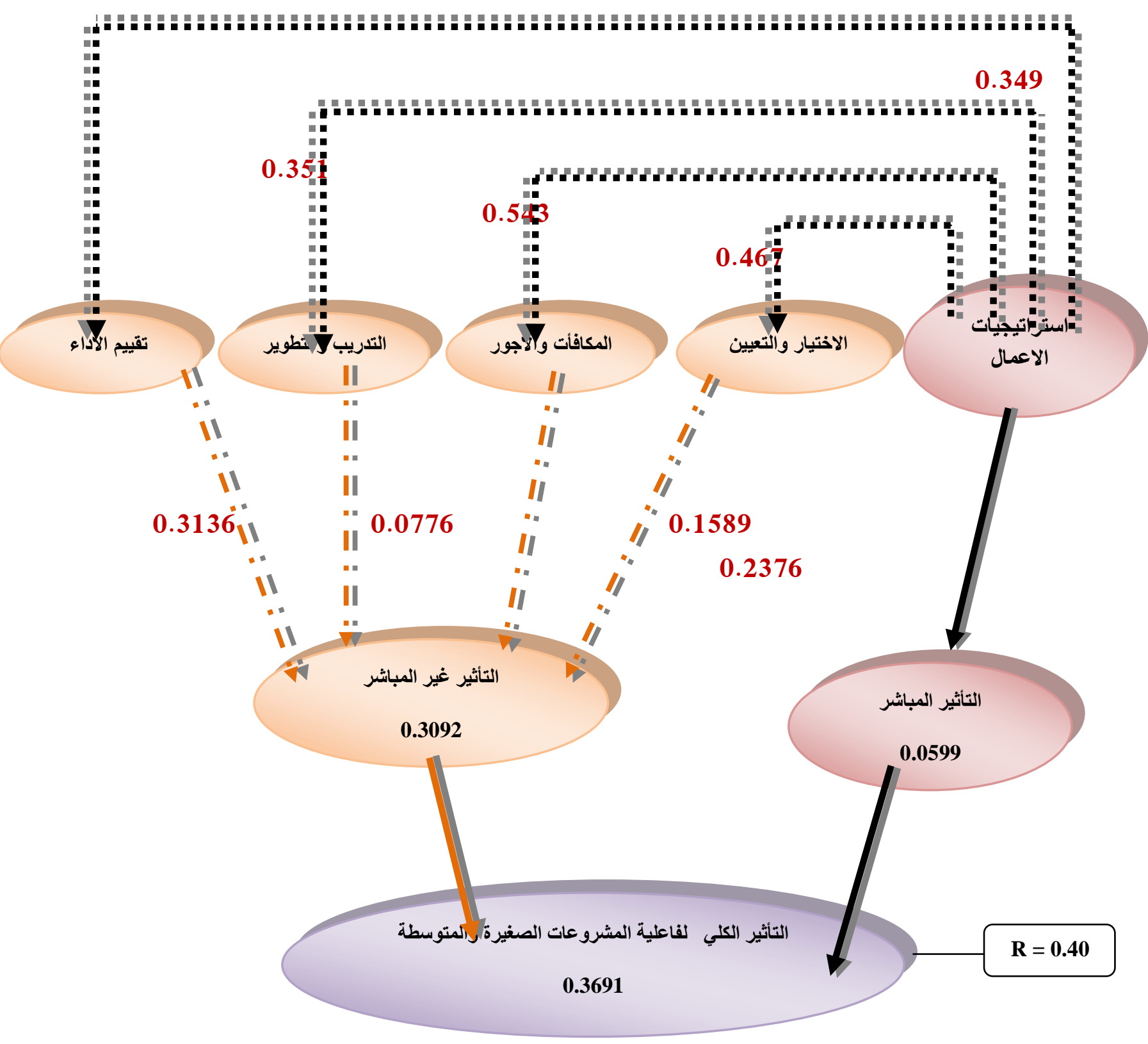

شكل ( 1 ) يوضح التأثير المباشر وغير المباشر للاستراتيجيات الاعمال في فاعلية المشروعات بتوسيط استراتيجيات إدارة الموارد البشرية 


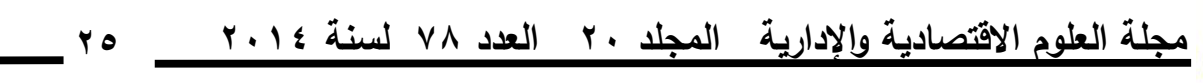

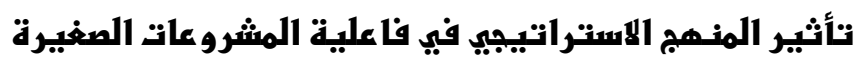
والمتوسطة في العراق - بـهث ميدانيي

\section{المحور الرابع \الاستنتاجات والتوصيات}

سيتم في هذا المحور التطرق الى اهم الاستنتاجات والتوصيات وكألاتي : اولا: الاستنتاجات

1. تسهم الاستراتيجية المدافعة مع كل من استراتيجية الاختيار والتعيين واستراتيجية التدريب والتطوير ،

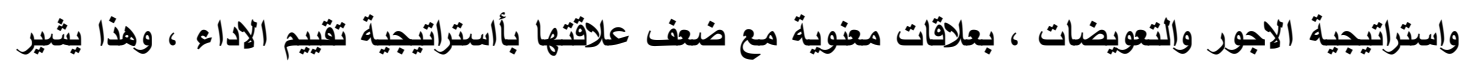

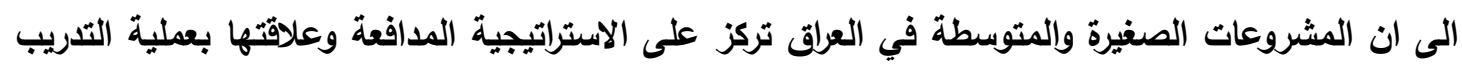
وتطوير الموارد البشرية ـ كما تدل هذه العلاقة على ان الاستراتيجية المدافعة تسهم في اختيار استراتيجية

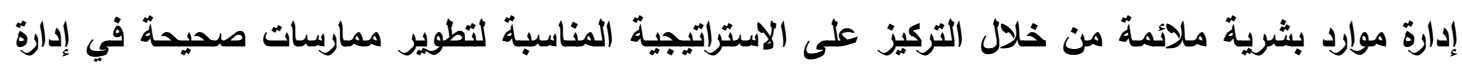

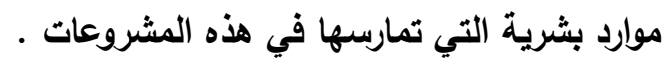
r. توضح ارتباط الاستراتيجية المنقبة مع استراتيجية الاختيار والتعيين بعلاقة معنوية ومع استراتيجية

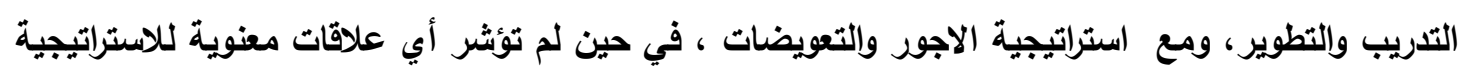

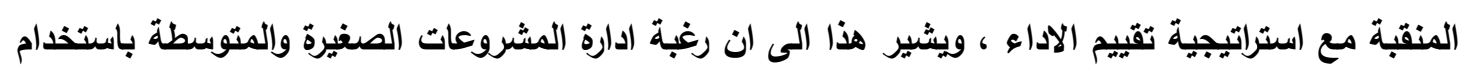

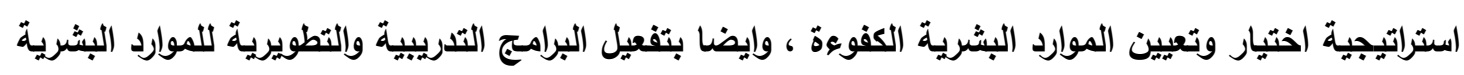

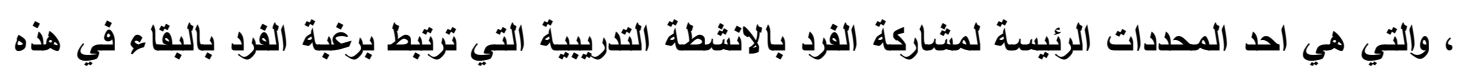

$$
\text { المشروعات . المئ. }
$$

r. حققت الاستراتيجية المحلة علاقات معنوية مع كل من استراتيجية الاختيار والتعيين و استراتيجية الاجور

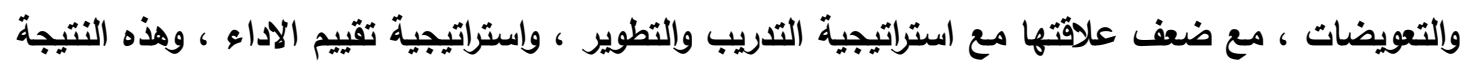

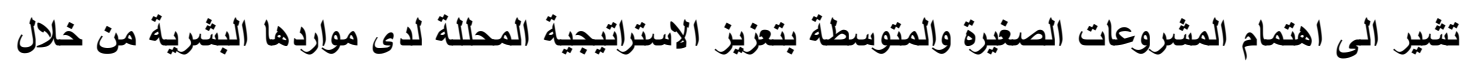

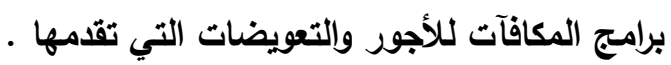

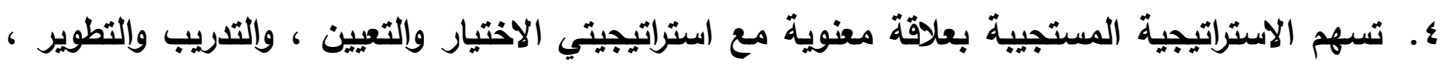

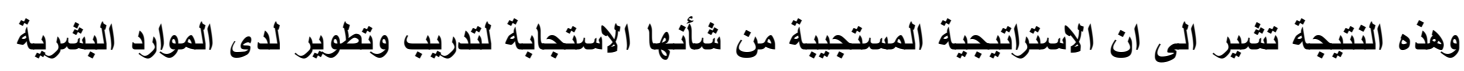
في العينة المبحوثة ، ويناء على هذه النتيجة يتضح ان الاستراتيجية المستجيبة ترتبط بيناء استراتيجيات إدارة الموارد البشرية في المشروعات ، ويسهم في تعزيزها من خلال تراكم الخبرات والتجارب التي تمر بهاء التهاتهات الموارد

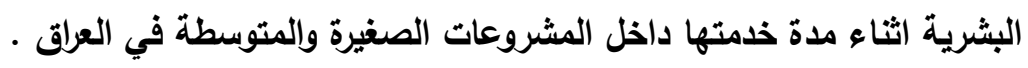

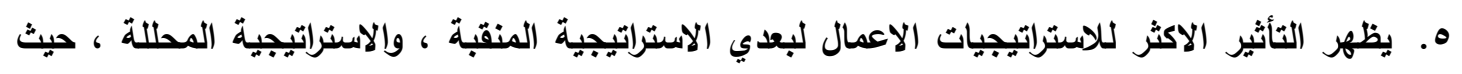

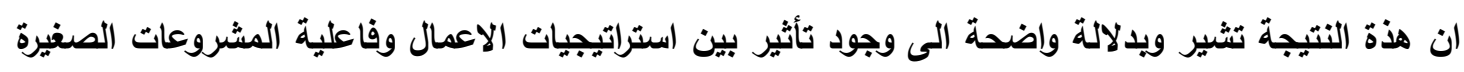
والمتوسطة بسبب وجود علاقتي تأثير ذات دلالة معنوية .

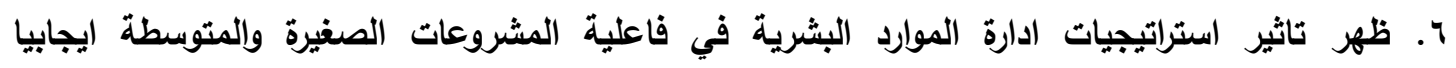
ومعنويا، حيث ان استراتيجية الاجور والتعويضات ، استراتيجية تقييم الاداء ، وهذة النتيجة تثير ويدلاتلة

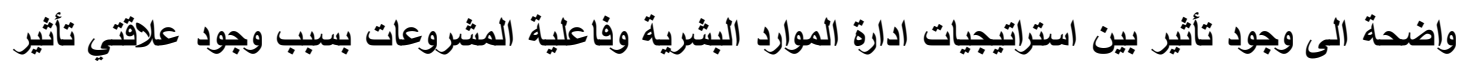

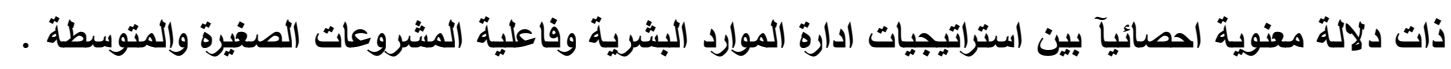

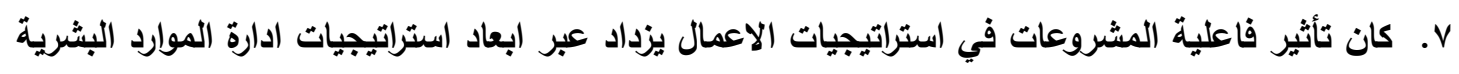
• وان تاثير الاستراتيجية المنقبة في فاعلية المشروعات يتعاظم ويشكل ايجابي عبر استراتيجية الاختيار 
والتعيين ، والتعويضات والاجور ، والتدريب والتطوير ، وتقييم الاداء ، اذن تؤكد النتائج السابقة على وجود

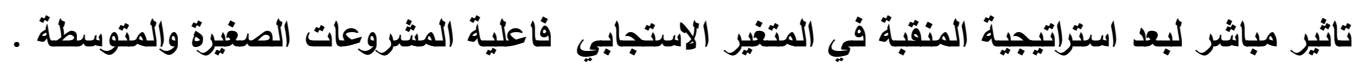
ثانيا : التوصيات :

1. ضرورة أستحداث هيئة متخصصة بأقامة المشروعات الصغيرة والمتوسطة في كل من وزارتي التخطيط والعمل والثؤون الاجتماعية تعنى بتقديم الدعم التقني والتجاري على شكل حزمة متكاملة ، وتقديم المشورة في مجال إستراتيجيات الموارد البشرية واستراتيجيات الاعمال واستراتيجيات التسويق والمحاسبة والمشاكل القانونية ، وفي مجال أعداد خطط الأعمال وإدارة المشاريع في إطار تنمية بشرية مستدامة تدفع باتجاه تعزيز وتنمية وتطوير المشاريع الصغيرة والمتوسطة في الاقتصاد العراقي وتسهم في تحيقيق الكفاءة والفاعلية لكلأقتصاد العراقي ككل .

r. ههم وتوعية اصحاب هذه المشروعات الى اهمية وجود استراتيجيات إدارة موارد بشرية في مشروعاتهم ،

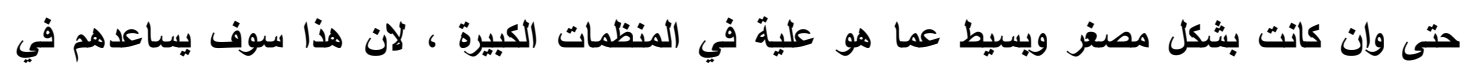

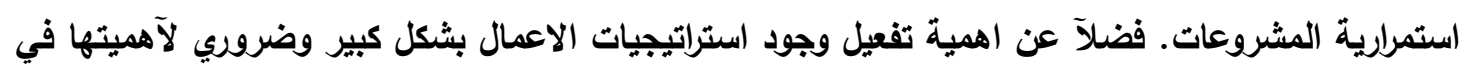
بقائهم في سوق العمل مع ما يتعرض له السوق من تغيرات كبيرة وسريعة وديناميكية في البيئة العالمية وعدام استقرارها لآسباب عديدة تؤثر بدورها على هذه المشروعات الصغيرة والمتوسطة ف يينبغي على اصحاب المشروعات وضع استراتيجية اعمال مناسبة بما يخدم المشروع لايهه.

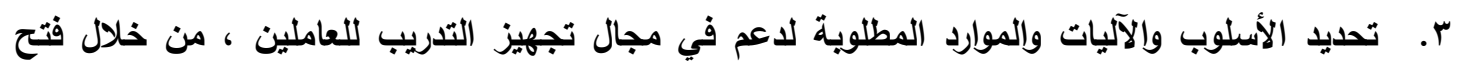
دورات تدريبية للعاملين في مجالات مختلفة ، زيادة مبلغ القروض الممنوحة من اجل ان يكون جزي منها

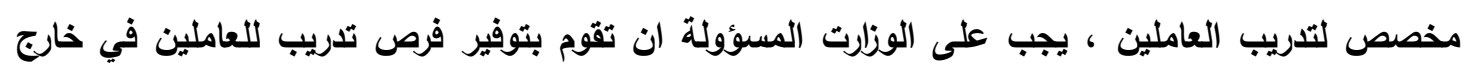

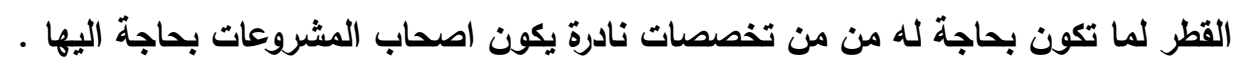

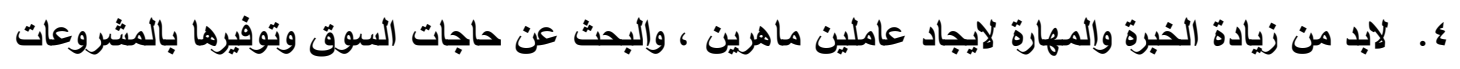

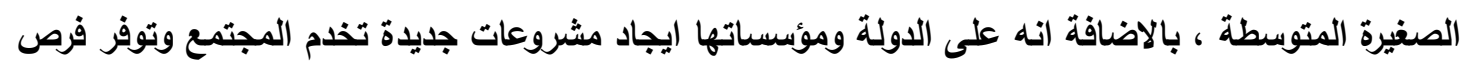

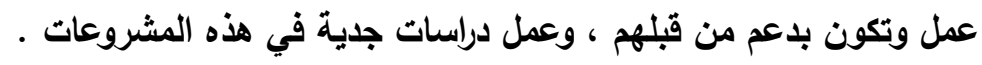

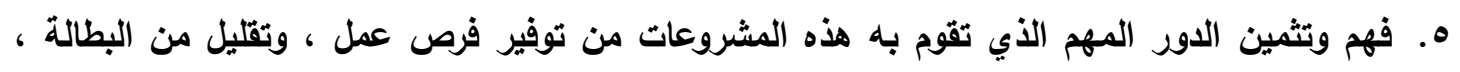

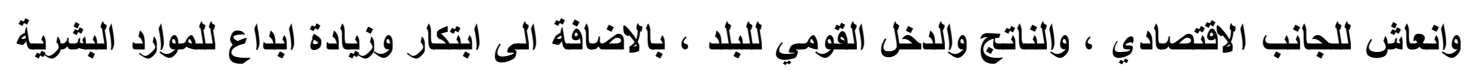

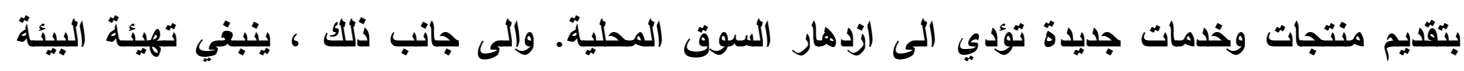

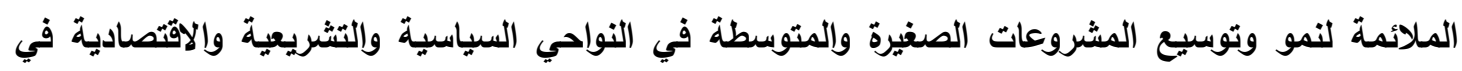
أطار إستراتيجية وطنية رسمية واضحة يشارك في صياغتها وتنفيذها جميع الجهات الحكومية وغير الحكومية

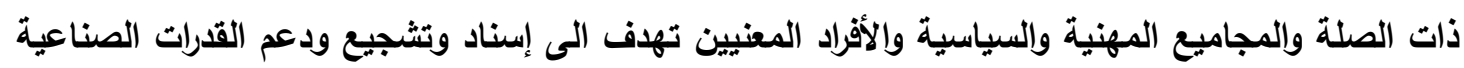
الصغيرة والمتوسطة والتوسع في استيعاب أكبر عدد ممكن من الثباب والمؤهل للعمل في هذا المجال .

المصسادر

العربية

1. العطية ، ماجدة عبد الستار ، (9 . . ؟) ، إدارة المشروعات العامة ، طبعة الاولى دار المسيرة للنشر 


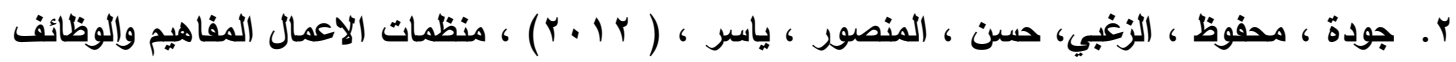
، دار وائل للنشر والتوزيع ، عمان ، الاردن .

r. الشيمي ، صلاح الدين حسن ، (9 . . r) ، " أستراتيجيات وآليات دعم وتنتمية المشروعات المتناهية الصغز والصغيرة والمتوسطة ودورها في التنمية الاقتصادية والاجتماعية في اطار المتغيرات العالمية والمحلية " قضايا اقتصادية معاصرة " ، دار الفكر العربي ، القاهرة ، جمهورية مصر العربية.

ع. الغالبي، طاهر محسن منصور، (2009) ،(إدارة وإستراتيجية منظمات الإعمال المتوسطة والصغيرة )

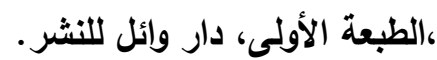

ه. محمد، محمود سلمان (2005)،" السلوك التنظيمي في منظمات الأعمال"، ط3، دار وائل للنشر والتوزيع، عمان

צ. . وزارة التخطيط والتعاون الإنمائي، الجهاز المركزي للإحصاء وتكنولوجيا المعلومات، المجموعة الإحصائية السنوي (2011 ) خلاصة نتائج الإحصاء الصناعي للمنشآت الصناعية الصغيرة .

1. Feigen, J ,Lawer,J (1996)."Organizational and Human Resource Management Strategies In Korea " impact on firm performance in an emerging economy, The Academy of Management Journal, Vol. 43, No.3

2. Carter, Ranall, (2000)," Managing Human Resource", 5 th ed, West Publishing Company, USA

3. Coutter, Laura, (2000), "Human Resource Management", 4 th ed ,London ,Prentice-Hall.

4. Denisi ,Thomas L, \& Griffin ,J.David (2001),"Strategic Management and Business Policy" Concepts, $9^{\text {th }}$ ed, Pearson Education ,Inc

5. $2^{\text {th }}$ ed, Prentice Hall Inc, New Jersey

6. Gratoon, Cardy.L (2000)," Managing Human Resources"

7. Bratton,Charles R(2003),"Strategic Human Resources Management" Pearson Custom Publishing, New Jersey

8. Marler .M, A, Lreland. Fishe .R,E ;(2013) strategic management competitiveness and globalization,. $4^{\text {th }}$ ed,south- westren college publishing, USA

9. Chen ., Song M ., 1999" the Relationship Between Strategic Type and Firm Capabilities . Mnak -Publications, New York .

10. Bergeron F Croteau C ., Raymond L ., 2001" Identification of Strategic . John Wiley \& Sons, New York .

11. Daft R ., 2001 " Organization Theory and Design " $7^{\text {th }}$ ed , USA, DPS Asso

12. Thompson, W ., 2003 " Business Policy and Strategic Management " $3^{\text {rd }}$ McGraw - Hill Book Co .

13. Apigian, et al ., 2002 " Miles and Snows Strategy Model in the Context of Small Firms . John Wiley \& Sons, New York .

14. Simon, et al ., 2005" Alignment of Firms Competitive . Mnak Publications, New York

15. Benedett, Jeffrey S . \& Song, Caron H . 2003 " Foundation in Strategic Management" By South - Western College Publishing . Printed in The United States of America,.

16. Apigian, el at, 2002 " Foundations in Strategic Management Cincinnati : 


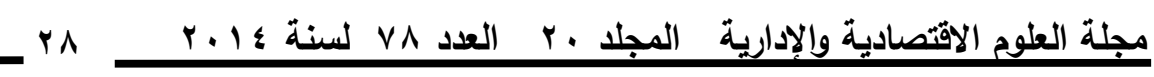

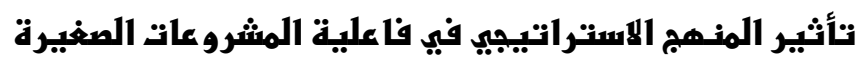

$$
\begin{aligned}
& \text { والمتوسطة في العراق - بـهث ميدانيي }
\end{aligned}
$$

John Wiley \& Sons, New York .

17. Garrigos J ., Marques N ., 2005" Strategic Alignment : Leveraging • Thomson Business Press . Printed in Italy

18. Benedett ., Blanchard ., 2003 " Management of Organization Behavior :

19. Utilizing Human Resources ${ }^{\text {th }}$ ed, Prentice - Hall , New Delhi .

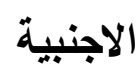

20. Ivanecivich, Yu Varaj, (1997), (Cases of Success Full Malaysian Small and Medium Enterprises: Does Business advisory services Heel?), Malaysian Accounting Research and Education foundation (Mare f)

21.Jones, Hua, W., (2001), "Searching for Competitive Advantage in The Black box", EMJ, Vol. (21), No. (2), April, pp. ( 222-236).

22.Koivisto, Mujtaba, B.G(2005),"SHRM and Global Expansion Lessons From The Euro Disney Challenges In France", International Business \& Economics Research Journal, Vol 8, No 1 p.p (69-78)

23.Nickels, Adrian, (2002), Common Dimensions For Entrepreneurship and Strategy: The Need for Strategic Entrepreneurship, Academy of Economic Studies, Bucharest.

24.Pooe, Matej, (2007), Tamper ton tame of managerial Skills and Knowledge in Management for Small Enterprise , E-Leader, Prague.

25.Pounder, Anthony, (1999) : Making Innovation Happen, Psychiatric Rehabilitation Journal , Sprring, Vol. 24 , Issue , 4

26.Rauch. L, Browm, K.G, (2000)," Human Resource Management", Linking Strategy To Practice, John Wiley \& Sons, Inc, USA

27.Richard 93- Rauch, et-al, 2005," Human Resource Management", $6{ }^{\text {th, }}$ ed Irwin,Inc,USA .

28.Robbins, S. P., (2004), "Organizational Behavior: Concepts, Controversies \& Applications", $3^{\text {th }}$ ed., N. J.: Prentice-Hall, Inc

29.Roberts, Michael, (2004) "Human resource management": A practical approach, $2^{\text {th }}$ ed., Harcourt college publisher, U.S.A

30.Savlovchl, Miriam , \& Robu, (2011), Report, (Policy Note micro, Small and Medium Enterprises development). Minister for Rural Industries

31.Schrier,D\&Hallin,L\&Johnson,K(,2005)" A profile of small business in British Columbia" the British Columbia Ministry of Labour and Citizens.

32.Van Gundy, Sigmand(2005)," The Organizational Success of New, Technology-based Firms", Ph.D. Thesis,( Stavanger University College) 


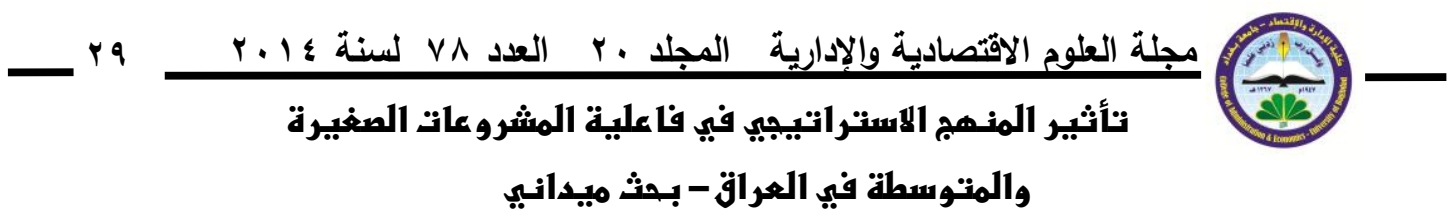

\section{The impact of strategic approach in the effectiveness of small and medium Enterprises in Iraq}

\section{Abstract:}

The purpose of this research highlight the achievement of the effectiveness of small and medium enterprises dimensions and conformable to analyze the relationship between business strategies and human resources management strategies, and launched search of a dilemma thought provoking fundamental questions revolve around the search is the lack of appropriate strategies in these enterprises to help them continuity and permanence in business and markets, as these enterprises lack the human resources management strategies appropriate , as well as business strategies that make them withstand the changes in the market environment is changing and volatile. It was to answer those questions through a theoretical framework for the variables search first and test models of the relationship and impact secondly through four hypotheses major, The objective of the research towards the effectiveness of small and medium enterprises with its various dimensions, according to the analysis of the relationship business strategies, and strategies for human resource management , out framework systematic intellectual brings together more dimensions and concepts, and try to test the Iraqi environment to embrace these modern concepts, following the descriptive analytical method. The researcher job questionnaire was selected a random sample of 100 people from the managers and staff responsible for these enterprises and directors of the jurisdiction of these projects in the Ministry of Planning and Labour and Social Affairs , and the hypothesis is the main research has addressed the extent of the impact the effectiveness of small and medium enterprises, the relationship between business strategies and strategies human resources management. The reported findings that human resources management strategies affect the effectiveness of the small and medium enterprises positive and morally, and the impact of the effectiveness of enterprises in business strategies positive and morally as well, and in addition to that it had reached the search to a set of conclusions, the most important is that the experience to create small and medium enterprises in Iraq is the experience of a young, not in the sense it is a new idea, but youthful experience of the state, which requires the support of this kind of projects and attention to their quality and development, as well as the development of human resources in which they operate, has included research five axes went first to the methodology and the second for framing theoretical and third analyze and discuss the exploratory to the field of small and medium - sized projects in Iraq, while the fourth dedicated diagnostic variables basic research and test hypotheses, and finally came fifth to introduce the conclusions and recommendations.

Key word : Small and medium-sized enterprises, effectiveness, business strategies, human resource management strategies. 